\title{
The Effect of Spirituality in the Workplace and Quality of Work Life on Nurses Performance in Regional General Hospital dr. Chasan Boesoerie of North Maluku
}

\author{
Marwan $^{1}$ \\ Adnan Rajak ${ }^{2}$ \\ Muhammad Ramdhani Abubakar ${ }^{3}$ \\ ${ }^{1}$ Fakultas Ekonomi, Universitas Khairun \\ ${ }^{2}$ Fakultas Ekonomi, Universitas Khairun \\ ${ }^{3}$ Fakultas Ekonomi, Universitas Khairun \\ rajak.adnan@yahoo.com
}

\begin{abstract}
The problems in this study are: (1) Does Spirituality in the workplace (workplace spirituality) affect the performance of nurses in the General Hospital dr. Chasan Boesoerie North Maluku Province?; (2) Does the quality of work life affect the performance of nurses in General Hospital dr. Chasan Boesoerie North Maluku Province?; and (3) Does Spirituality in the workplace (workplace spirituality) affect the quality of work life (quality of worklife) in the General Hospital dr. Chasan Boesoerie North Maluku Province?. The purpose of this study was to determine the effect of Spirituality in the workplace and the quality of work life on nurse performance, and the influence of Spirituality in the workplace on the quality of work life in RSUD dr. Chasan Boesoerie North Maluku Province. The total population target is 326 nurses. The sampling method or technique used is random sampling, which is random sampling. Based on the sample formula from Taro Yamane, a study sample of 180 nurses was obtained. The analytical model used to test hypotheses is path analysis and using LISREL as a statistical test tool.

The results of the study found that: (1) spirituality in the workplace had a positive and significant effect on nurse performance; (2) Quality of work life has a positive and significant effect on nurse performance; and (3) Workplace Spirituality has a positive and significant effect on the quality of work life. Because of that General Hospital dr. Chasan Boesoerie needs to improve spirituality through: 1) creating an adequate work environment, 2) providing motivation to nurses through training including in the job trainning, 3) providing opportunities for nurses to reevaluate the results of their work assessment, and 4) giving understanding of the nurses about the organization's vision, mission and goals in detail. This can be done through workshops, or official programmed meetings. For other researchers who want to develop this research, it is necessary to conduct research that uses the same or different variables that have an influence on performance.
\end{abstract}

Keywords: Nurses Performance, Quality of Work Life, and Workplace Spirituality 


\section{PENDAHULUAN}

Era globalisasi menuntut berbagai organisasi pada umumnya dan khususnya organisasi sektor publik harus memberikan layanan terbaik atau memuaskan masyarakat. Rumah sakit umum daerah sebagai organisasi publik harus dapat memberikan nilai lebih kepada pasiennya sebagai konsumen dalam berbagai layanan kesehatan. Nilai atau layanan kesehatan yang sesuai harapan konsumen dapat diberikan bilamana rumah sakit memiliki sumber daya-sumber daya yang memadai. Salah satu sumber daya utama adalah sumber saya manusia, karena manusia merupakan penggerak sumber daya lainnya. Dengan kata lain, manusia (karyawan atau perawat) sebagai sumber daya utama harus disinergikan dengan sumber daya lainnya seperti: dana, sarana, dan prasarana dalam melakukan berbagai aktivitas layanan kesehatan kepada masyarakat atau pasien.

Masyarakat sebagai pengguna layanan kesehatan rumah sakit baik rumah sakit umum maupun rumah sakit swasta, perlu mengelola sumber daya manusia sesuai dengan tata kelola rumah sakit. Artinya, pihak rumah sakit tidak hanya mementingkan kepentingan organisasinya, tetapi kepentingan masyarakat (pasien) juga perlu di perhatikan melalui berbagai evaluasi baik seara internal maupun eksternal. Karena itu, pengelolaan (management) rumah sakit dituntut untuk lebih profesional dan konsisten menjalankan fungsi sosial rumah sakit dalam memberikan pelayanan kesehatan kepada masyarakat.

Menurut Undang-Undang Republik Indonesia Nomor 44 Tahun 2009 tentang rumah sakit bahwa, rumah sakit adalah institusi pelayanan kesehatan yang menyelenggarakan pelayanan kesehatan perorangan secara paripurna yang menyediakan pelayanan rawat inap, rawat jalan, dan gawat darurat. Karena itu, sebagaimana hal tersebut maka Rumah Sakit Umum Daerah (RSUD) dr. Chasan Boesoerie di Provinsi Maluku Utara merupakan organisasi sektor publik yang sangat memerlukan sumber daya manusia untuk melakukan berbagai layanan kesehatan seperti: rawat inap, rawat jalan, dan gawat darurat. Selain itu, rumah sakit juga merupakan tempat menyelenggarakan upaya kesehatan yaitu setiap kegiatan untuk memelihara dan meningkatkan kesehatan dengan tujuan untuk mewujudkan derajat kesehatan yang optimal bagi masyarakat. Dengan demikian, kinerja organisasi atau kualitas layanan kesehatan rumah sakit umum sangat ditentukan kinerja atau hasilhasil kerja perawat.

Berdasarkan pengamatan dilapangan dan hasil wawancara terkait dengan kinerja perawat menunjukan bahwa: (1) masih adanya tugas pokok perawat yang belum sesuai dengan tujuan rumah sakit umum; (2) belum adanya perbaikan secara terusmenerus didalam melaksanakan tugas pokok perawat; (3) masih ada perawat yang bekerja belum sesuai dengan standard operating procedure; (4) Volume kerja yang dihasilkan belum sesuai dengan jumlah beban kerja yang ditentukan oleh pimpinana; 
(5) masih adanya prawat yang belum menjelaskan maksud dari pekerjaan ketika dibutuhkan oleh manajemen rumah sakit; (6) kurang adanya kerja sama diantara para perawat; dan (7) masih adanya perawat yang belum memanfaatkan waktu luang untuk menganalisis kualitas dan kuantitas tugas pokok.

Kinerja perawat di rumah sakit secara langsung mempengaruhi kinerja atau tujuan dari organisasi rumah sakit dr. Chasan Boesoer, tetapi masih perlu untuk dikaji lebih jauh terkait dengan faktor-faktor yang mempengaruhi kinerja tugas. Terdapat berbagai faktor atau variabel yang mempengaruhi kinerja perawat, namun demikian dalam penulisan ini yang akan diteliti adalah variabel spritualitas di tempat kerja, dan kualitas kehidupan kerja. Hal ini dapat juga dilihat berdasarkan pada hasil penelitian terdahulu yang dilakukan oleh Javanmard (2012: 1964) menunjukan bahwa spiritualitas (spirituality) di tempat kerja yang terdiri dari: makna dan tujuan hidup (inner life), meaning full at work, sense of communitberpengaruh kinerja karyawan, dan hasil penelitian Arifin (2012: 17) menunjukan bahwa kualitas kehidupan kerja berpengaruh positif dan signifikan terhadap kinerja karyawan.

Berdasarkan fenomena dan hasil penelitian terdahulu di atas menunjukan bahwa, kinerja karyawan atau kinerja perawat dipengaruhi variabel tertentu diantaranya adalah spiritualitas di tempat kerja (workplace spirituality) dan kualitas kehidupan kerja (quality of worklife). Menurut Robbins dan Judge (2011: 529) spritualitas ditempat kerja adalah kesadaran bahwa orang memiliki kehidupan batin yang tumbuh dan ditumbuhkan oleh pekerjaan yang bermakna yang berlangsung dalam konteks komunitas. Lebih lanjut dijelaskan bahwa, organisasi yang mendukung budaya spritualitas mengakui bahwa manusia memiliki pikiran dan jiwa, berusaha mencari makna dan tujuan dalam pekerjaan mereka, dan hasrat yang berhubungan dengan orang lain, serta menjadi bagian dari sebuah komunitas. Sedangkan Newstrom dan Davis (2002: 244), Quality of Work Life (QWL) adalah cara organisasi dimana mereka bertanggung jawab terhadap pengembangan dan kondisi kerja yang lebih baik (sehat dan aman) untuk pekerja, yang mana hal ini akan berpengaruh terhadap kesehatan ekonomi organisasi.

Berdasarkan wawancara dan pengamatan dipalangan terkait dengan workplace spirituality di RSUD dr. Chasan Boesoeirie menunjukan bahwa: (1) kondisi atau lingkungan kerja belum sepenuhnya membuat perawat nayaman dalam bekerja; (2) tidak semua perawat mendapatkan kesempatan untuk mengemukakan pendapat atau ide terkait dengan masalah pekerjaan; (3) masih ada perawat yang tidak saling mendukung dalam menyelesaikan masalah pekerjaan; dan (4) masih adanya perawat tidak memahami visi, misi, dan tujuan organisasi (RSUD dr. Chasan Boesoerie).

Perawat juga merupakan sumber daya manusia yang diharuskan bekerja sesuai dengan tujuan yang telah ditetapkan oleh rumah sakit umum daerah. Dengan kata lain, dalam perspektif manajemen sumberdaya manusia, khususnya berhubungan dengan spiritualitas di tempat kerja dan kualitas kehidupan kerja dalam mempengaruhi kinerja 
perawat perlu diteliti. Karena itu, peneliti akan meneliti tentang: "Pengaruh Spiritualitas di Tempat Kerja dan Kualitas Kehidupan Kerja terhadap Kinerja Perawat di RSUD dr. Chasan Boesoerie Provinsi Maluku Utara".

\section{Rumusan Masalah}

Berdasarkan pada latar belakang masalah, maka dapat dirumuskan masalah penelitian sebagai berikut:

1. Apakah Spiritualitas di tempat kerja (workplace spirituality) berpengaruh terhadap Kinerja perawat di RSUD dr. Chasan Boesoerie Provinsi Maluku Utara ?

2. Apakah kualitas kehidupan kerja berpengaruh terhadap Kinerja perawat di RSUD dr. Chasan Boesoerie Provinsi Maluku Utara?

3. Apakah Spiritualitas di tempat kerja (workplace spirituality) berpengaruh terhadap kualitas kehidupan kerja (quality of worklife) di RSUD dr. Chasan Boesoerie Provinsi Maluku Utara?

\section{TINJAUAN PUSTAKA}

\section{Penelitian Terdahulu}

Peneltian yang dilakukan oleh Javanmard(2012: 1964) menunjukan bahwa spiritualitas (spirituality) di tempat kerja yang terdiri dari: makna dan tujuan hidup (inner life),meaning full at work, sense of communitberpengaruh kinerja karyawanberpengaruh positif terhadap kinerja karyawan; (2) stres kerja berpengaruh negatif terhadap kepuasan kerja dan kinerja karyawan; (3) kepuasan kerja berpengaruh positif terhadap kinerja karyawan.

Peneltian yang dilakukan oleh Duchon (2012: 200-202) menggunakan model regresi linear berganda menunjukan bahwa, spiritualitas di tempat kerja (workplace spirituality) yang terdiri dari: rasa sayang (compassion), rasa perhatian (meaningfulness) perasaan bermakna (meaningful work), dan kelebihan beban kerja (transcendence) berpengaruh positif terhadap kinerja karyawan dan Praktek meditasi (meditation practice). Praktek meditasi berpengaruh positif terhadap kinerja karyawan. Selain itu, workplace spirituality berpengaruh positif secara tidak langsung terhadap employee performance melalui praktek meditasi.

Penelitian yang dilakukan oleh Pradhan, Panigrahy, dan Jena (2015: 45) menyimpulkan bahwa, spiritualitas di tempat kerja membantu karyawandi area kreativitas, perbaikan proses, layanan pelanggan, kejujuran dan kepercayaan, dan komitmen, yang pada akhirnya menyebabkan peningkatan Kinerja organisasi. Organisasi yang mendorong pengalaman spiritualitas meningkatkan kinerja organisasi dan profitabilitas dengan memberdayakan karyawan untuk menunjukkan keberagaman tugas dan non-tugas terkait perilaku. Hal ini memfasilitasi karyawan untuk menjadi lebih berkomitmen pada pekerjaan dan membantu mereka untuk 
perbaikan dan kemajuan organisasi. Jadi, hal ini benar-benar mengungkapkan bahwa karyawan dan pimpinan perlu untuk menggabungkan spiritualitas di tempat kerja karena membantu karyawan untuk berkontribusi lebih dengan memungkinkan mereka untuk memahami gambaran besar dan manfaat organisasi secara keseluruhan.

Peneltian yang dilakukan oleh Arifin (2012: 17) menggunakan model Model persamaan structural Partial Least Square (PLS) menunjukan: (1) kualitas kehidupan kerja (quality of work life) berpengaruh positif dan signifikan terhadap kinerja karyawan; (2) kualitas kehidupan kerja berpengaruh positif dan signifikan terhadap kepuasan kerja; (3) kepuasan kerja berpengaruh positif dan signifikan terhadap kinerja karyawan. Selain itu, kualitas kehidupan kerja memiliki pengaruh yang lebih besar dari kepuasan kerja terhadap kinerja karyawan.

Peneltian yang dilakukan oleh Otiende (2014: 32-34) menggunakan model regresi linear berganda menunjukan: (1) kualitas kehidupan kerja berpengaruh positif dan signifikan terhadap tenaga kerja operasional, asministrasi, dan para manajer; dan (2) kualitas kehidupan kerja berpengaruh positif dan signifikan terhadap kinerja tugas dan pengalaman kerja. Mendukung penelitian hasil penelitian yang dilakukan oleh Parmin (2014: 102-103) menunjukkan bahwa, kompetensi dan disiplin kerja secara bersama-sama mempunyai pengaruh positif yang signifikan terhadap kinerja pegawai PD BPR BKK Kebumen. Selanjutnya, hasil penelitian yang dilakukan oleh Irawati (2015: 51) juga menunjukan bahwa: kualitas kehidupan kerja $(X)$ yang meliputi: Pertumbuhan dan Pengembangan, Partisipasi, dan Lingkungan Kerja berpengaruh signifikan dan positif terhadap Kinerja Pegawai.

Peneltian yang dilakukan oleh Hojjati dan Hamidi (2015: 24) menggunakan model regresi linear berganda menunjukan bahwa: Perasaan bermakna dalam pekerjaan (Meaningful work), Perasaan terhubung dengan komunitas (sense of community), dan Penegakan nilai-nilai (alignment of values) berpengaruh positif dan signifikan terhadap kualitas kehidupan kerja (quality of work life).

\section{Landasan Teori \\ Spritualitas di Tempat Kerja (Workplace Spirituality)}

Spritualitas ditempat kerja (workplace spirituality) disebutkan secara beragam dalam literatur. Menurut Mulyono (2010: 25) dalam tesisnya menjelaskan bahwa ada yang menggunakan istilah workplace at work (Marques, 2008), spirituality in the workplace (Mtroft dan Denton, 1999), dan workplace spirituality (Zamor, 2003). Dalam konteks universal, spritualitas (spirituality) diartikan Beazley dalam Strack, et al. (2002) sebagai, "a faith relationship with the transcendent, that is, trust in, and loyality on, conters of value that are of ultimate concern to human being and the images of power whith which that individual aligns himself or herself and upon which he or she acts, and order to survive in an uncertain world". Artinya, hubungan iman dengan transenden 
(keyakinan), yakni kepercayaan, dan loyalitas pada pusat nilai yang menjadi perhatian utama untuk manusia dan gambaran kekuasaan dan atas tindakan individu atas nama dirinya sendiri, dan untuk bertahan hidup di dunia yang tidak pasti.

Sedangkan Chandra dalam Aburahman dan Agustini (2011: 529) mengemukakan bahwa spritualitas adalah kesediaan dan kemampuan untuk menggali makna dan kenyataan-kenyataan hidup. Sedangkan Gibon dalam Dent, et al., (2005: 34) mendefinisikan spritualitas sebagai "the search of direction, meaning, inner wholeness dan connection to others, to non-human creation, and to a trancedent". Berdasarkan definisi spritualitas ini menunjukan bahwa makna spritualitas berdasarkan pada aktivitas individual yang berorientasi pada kemampuannya dalam mencari makna dalam kehidupannya. Artinya, spritualitas yang bersifat universal. Namun demikian, jika dihubungkan dengan tempat kerja atau spirituality in the workplace (spritualitas ditempat kerja) menurut Robbins dan Judge (2011:529) sama sekali tidak berhubungan dengan praktik religious yang terorganisasi atau bukan tentang tuhan dan teologi. Robbins dan Judge (2011:529) mendefinisikan "workplace spirituality as the recognition that people have an inner life that nourishes and is nourished by meaningful work that takes place in the context of community". Artinya, spritualitas ditempat kerja adalah kesadaran bahwa orang memiliki kehidupan batin yang tumbuh dan ditumbuhkan oleh pekerjaan yang bermakna yang berlangsung dalam konteks komunitas. Lebih lanjut dijelaskan bahwa, organisasi yang mendukung budaya spritualitas mengakui bahwa manusia memiliki pikiran dan jiwa, berusaha mencari makna dan tujuan dalam pekerjaan mereka, dan hasrat yang berhubungan dengan orang lain, serta menjadi bagian dari sebuah komunitas.

Fox dalam Ashmos dan Duchon (2000: 137) menyatakan bahwa untuk memahami istilah spritualitas di tempat kerja harus diawali dengan "acknowledging that people have both an inner on outer life and that the nourishment of the inner life can lead to a more meaningful and productive outer life". Artinya, pengakuan bahwa setiap orang memilik sesuatu kehidupan pribadi (inner) dan kehidupan luar (outer), dan bahwa pengembangan kehidupan peribadi dapat mengakibatkan kehidupan luar yang lebih bermakna dan lebih produktif. Lebih lanjut dijelaskan oleh Ashmos dan Duchon (2000) menyatakan bahwa, "the recohnition of sprituality in the workplace means seeing the workplace as populated by people who have both a mind and a spirit and believing that the development of the spirit is as important as the development of the mind". Artinya, pengakuan terhadap spiritualitas di tempat kerja berarti memandang tempat kerja sebagai suatu tempat yang dihuni oleh orang-orang yang memiliki pikiran (akal) dan semangat, dan meyakini pengembangan semangat adalah sama pentingnya dengan pengembangan pikiran.

Uraian di atas menunjukan bahwa spritualitas di tempat kerja terkait dengan orang atau individu ditempat kerja yang saling memerlukan atau adanya rasa solidaritas sesama manusia atau anggota organisasi. Hal sebagaimana menurut 
menurut Gibbons (2001) dalam hakim dan Azlimin (2015: 346) bahwa, spiritualitas di tempat kerja termasuk konsep integritas dan solidaritas dalam bekerja dan memahami nilai-nilai yang mendalam dalam pekerjaan. Sementara itu menurut Mitroff dan Denton (1999), dalam hakim dan Azlimin (2015: 346) bahwa, spiritualitas di tempat kerja yaitu upaya untuk mencari dan menemukan makna tertinggi kehidupan untuk kehidupan kerja, untuk berkomunikasi antara individu dan rekan-rekan mereka serta orang-orang lain yang entah bagaimana berkontribusi terhadap pekerjaan, juga harmoni atau kesatuan antara kepercayaan individu dengan nilai organisasi mereka. Kinjerski dan Skrypnek (2004) dalam hakim dan Azlimin (2015: 346) spiritualitas di tempat kerja adalah pengalaman yang berbeda dicirikan oleh fitur kognitif, dimensi interpersonal, kehadiran spiritual, dan komponen mistis.

Menurut Giacolone \& Jurkiewics dalam dalam Nurtjahjanti (2010: 29): Provide the following definition: "Aspects of the workplace, either in the individual, the group, or the organization, that promotes individual feelings of satisfaction through transcendence. To elaborate, that the process of work facilitates employees sense of being connected to a non-physical force beyond themselves that provide feelings of completeness and joy." (Spiritualitas dalam pekerjaan didefinisikan sebagai kerangka kerja dari nilai-nilai budaya organisasi yang mendorong pengalaman transenden para karyawan melalui proses bekerja, memfasilitasi perasaan dari hubungan mereka dengan orang lain sekaligus memberikan mereka perasaan lengkap dan bahagia). Maksud dari definisi tersebut adalah spritualitas ditempat kerja merupakan kerangka kerja dari nilai-nilai budaya organisasi yang mampu mendorong karyawan untuk tetap bekerja secara konsisten, dimana organisasi perlu untuk memfasilitasi kepentingan karyawan secara komprehensif untuk memenuhi totalitas kepuasan kerja karyawan.

Sedangkan menurut Neck dan Milliman dalam Litzsey (2003) mengemukakan bahwa spiritualitas dalam pekerjaan adalah tentang mengekspresikan keinginan diri untuk mencari makna dan tujuan dalam hidup dan merupakan sebuah proses menghidupkan satuan set nilai-nilai pribadi yang sangat dipegang oleh seseorang. Hal ini menunjukan bahwa, seseorang yang mampu memaknai secara positif tujuan kehidupan pekerjaannya, maka ia akan mampu memberikan kontribusi positif kepada organisasi atau tempat kerjanya. Dengan kata lain, spiritualitas dalam pekerjaan akan menghasilkan hal-hal positif bagi karyawan dan organisasi. Hal ini sebagaimana pendapat Litzsey (2003) bahwa mengintegrasikan spiritualitas di tempat kerja, akan membuat karyawan merasakan makna dan perasaan bertujuan dalam kehidupannya. Lebih lanjut dijelaskan, organisasi tidak hanya membuat karyawan merasa utuh sebagai pribadi, tetapi juga memberikan keuntungan bagi perusahaan dalam hal keuntungan, moral yang tinggi dan penurunan tingkat absensi karyawan.

Mendukung pendapat Litzsey (2003), Mitroff dan Denton dalam Miliman et al. (2006:43) menjelaskan bahwa, "workplace spirituality involves the effort to find one's ultimate purpose in life, to develop a strong connection to coworkers and other people 
associated with work, and to have consistency (or aligment) between one's core beliefs and values of their organization". Maksud dari pernyataan ini adalah spiritualitas di tempat kerja merupakan usaha organisasi untuk menemukan tujuan hidup yang sangat penting, mengembangkan hubungan kemitraan kerja yang kuat, dan mempertahankan konsistenan antara keyakinan inti pegawai dengan nilai-nilai organisasinya. Dengan kata lain, spritualitas di tempat kerja pada prinsipnya merupakan sinergitas usaha organisasi dan anggota organisasi dalam memaknai dan mencapai tujuan dari pekerjaan.

Penjelasan di atas menunjukan bahwa, spritualitas di tempat kerja tidak hanya berkaitan dengan usaha atau upaya individual untuk memaknai tujuan dari sebuah pekerjaan di tempat kerja, akan tetapi organisasi perlu untuk mensinergikannya melalui proses fasilitasi berbagai keperluan anggotanya untuk tetap bekerja sesuai dengan tujuan organisasi. Sejalan dengan hal ini, menurut Parvar (2008) dalam Mulyono (2010:25) bahwa workplace spirituality dipandang dalam dua perspektif, yaitu perspektif individual yakni, pengalaman individu dalam menerapkan nilai-nilai spiritualitas pribadi dalam organisasi. Sedangkan perspektif organisasional yaitu suatu kerangka nilai organisasi yang dibuktikan dengan adanya budaya yang memfasilitas individu untuk menerapkan spritualitas dalam organisasi (menikmati kesenangan bekerja dan merasa terhubung satu sama lain). Lebih lanjut Kolodinsky, dkk., (2008) menambahkan persepktif yang ketiga yaitu, suatu proses interaksi dari keduanya (individual dan organisasi).

Terkait dengan keseluruhan penjelasan di atas, maka spritualitas di tempat kerja perlu dipelajari atau diketahui baik secara indivdiu maupun organisasi. Karena itu, variabel tersebut perlu diindentifikasi ukuran-ukuran atau indikatornya. Menurut Ashmos dan Duchon (2000:137) terdapat 3 dimensi yaitu: (1) Inner life (kehidupan pribadi/batin), (2) meaningfull work (kerja yang bermakna), dan (3) community (komunitas/kelompok).Sedangkan menurut Milliman dkk, 2003 dalam Amalia dan Yunizar (2011:4), dan Yogatama dan Widyarini (2015:6), ada tiga dimensi utama workplace spirituality, yaitu purpose in one's work atau "meaningful work", having a "sense of community", dan being in "alignment with the organization's values" and mission. Masing-masing dimensi tersebut mewakili tiga level dari workplace spirituality, yaitu (1) individual level, (2) group level, dan (3) organizational level. Penjelasan adalah sebagai berikut:

Meaningful work mewakili level individu. Hal ini adalah aspek fundamental dari workplace spirituality, terdiri dari memiliki kemampuan untuk merasakan makna terdalam dan tujuan dari pekerjaan seseorang. Dimensi ini merepresentasikan bagaimana pekerja berinteraksi dengan pekerjaan mereka dari hari ke hari di tingkat individu. Hal ini didasarkan pada asumsi bahwa manusia memiliki motivasi terdalamnya sendiri, kebenaran dan hasrat untuk melaksanakan aktivitas yang mendatangkan makna bagi kehidupannya dan kehidupan orang lain. Bagaimanapun 
juga, spiritualitas melihat pekerjaan tidak hanya sebagai sesuatu yang menyenangkan dan menantang, tapi juga tentang hal-hal seperti mencari makna dan tujuan terdalam, menghidupkan mimpi seseorang, memenuhi kebutuhan-kebutuhan hidup seseorang dengan mencari pekerjaan yang bermakna, dan memberikan kontribusi pada orang lain.Sense of community mewakili level kelompok. Dimensi ini merujuk pada tingkat kelompok dari perilaku manusia dan fokus pada interaksi antara pekerja dan rekan kerja mereka. Pada level ini spiritualitas terdiri dari hubungan mental, emosional, dan spiritual pekerja dalam sebuh tim atau kelompok di sebuah organisasi. Inti dari komunitas ini adalah adanya hubungan yang dalam antar manusia, termasuk dukungan, kebebasan untuk berekspresi, dan pengayoman. Aspek fundamental yang ketiga adalah alignment with organizational values yang mewakili level organisasi. Aspek ke tiga ini menunjukkan pengalaman individu yang memiliki keberpihakan kuat antara nilai-nilai pribadi mereka dengan misi dan tujuan organisasi. Hal ini berhubungan dengan premis bahwa tujuan organisasi itu lebih besar daripada dirinya sendiri dan seseorang harus memberikan kontribusi kepada komunitas atau pihak lain (Milliman dkk, 2003 dalam Amalia dan Yunizar, 2011:4).Sedangkan berbagai studi literatur Gupta dan Saini (2014:439) merumuskan indikator dari workplace sprituality sebagai berikut: Makna Kerja (Meaningful Work): hal ini mencerminkan perasaan individu atas apa yang dianggap penting, berenergi, dan menyenangkan terkait dengan pekerjaan. Dengan kata lain, makna di tempat kerja adalah totalitas rasa dan harmonisasi dengan beberapa hal yang menjiwai (lebih tinggi) tujuan yang memberikan arahan kepada pekerja (karyawan). Hal ini juga dikemukakan Overell dalam Gupta dan Saini (2014:439) bahwa, meaning berkaitan dengan apakah tujuan dan signifikansi dirasakan di tempat kerja.Sense of Community: Dimensi kedua ini didasarkan pada gagasan bahwa makhluk hidup spiritual dalam kaitannya dengan manusia lain dan di sini masyarakat mengacu pada pengertian tentang berbagi (sharing), saling membantu dan berkomitmen yang menghubungkan orang yang satu dengan lainnya.Mencari tujuan dan makna (Search for purpose and meaning): terkait dengan keinginan dasar untuk menemukan makna dan tujuan hidup seseorang dan untuk menjalani kehidupan yang terintegrasi. Atau mencari makna, tujuan, dan integrasi dalam kehidupan.

\section{Kualitas Kehidupan Kerja}

Kualitas kehidupan kerja adalah suatu cara pikir tentang orang-orang, pekerjaan, dan organisasi yang memusatkan perhatian pada dampak pekerjaan terhadap pekerja dan efektivitas organisasional, disamping memberikan gagasan-gagasan partisipatif dalam memecahkan masalah-masalah organisasional dan pembuatan keputusan (Anatan dan Ellitan, 2007:74). Kualitas kehidupan kerja terdiri dari dua elemen utama, yaitu: (1) Adanya perhatian tentang dampak pekerjaan pada pekerja dan efektivitas 
organisasi; dan (2) Adanya gagasan partisipasi dalam pemecahan masalah organisasional dan pembuatan keputusan (Nedler dan Lawler, yang dikutip oleh Anatan dan Ellitan, 2007:75). Sedangkan menurut Stone J., (2005:168) bahwa Kualitas kehidupan kerja, meliputi pelaksanaan kebijakan dan praktek-praktek HRM, dirancang untuk meningkatkan kinerja organisasi dan kesejahteraan karyawan (termasuk gaya manajemen, kebebasan untuk membuat keputusan, upah dan keuntungan, kondisi kerja, keselamatan, dan pekerjaan penuh arti.

Berdasarkan kedua definisi tersebut di atas menunjukan bahwa, pendapat Anatan melihat kualitas kehidupan kerja (quality of work life) sebagai salah satu upaya organisasi dalam menganalisis efek dari pekerjaan secara keseluruhan terhadap karyawan. Sedangkan pendapat Stone J., fokus pada faktor-faktor yang harus diperhatikan organisasi untuk mendukung kualitas kehidupan kerja karyawan melalui penghargaan, keamanan, dan peluang karir. Mendukung pernyataan ini Newstrom dan Davis (2002:244), Quality of Work Life (QWL) adalah "Another way in which organizations recognize their responsibility to develop jobs and work-way conditions that are excellent for people as well as for the economic health of the organization". Maksud dari definisi ini adalah kualitas kehidupan kerja adalah cara organisasi dimana mereka bertanggungjawab terhadap pengembangan dan kondisi kerja yang lebih baik (sehat dan aman) untuk pekerja, yang mana hal ini akan berpengaruh terhadap kesehatan ekonomi organisasi.

Sejalan dengan hal di atas, Greenberg dan Baron (2003:612) mengemukakan quality of work life (QWL) adalah "An Organizational Development technique improve organizational functioning by humanizing the workplace, making it more democratic, and involving employees in decision making". Maksudnya adalah Kualitas kehidupan kerja merupakan teknik pengembangan oragnisasional dalam meningkatkan fungsi organisasi berkaitan dengan karyawan dalam mendapatkan perlakuan secara adil, demokratis dan karyawan dilibatkan dalam pengambilan keputusan ditempat kerja.

Menurtut Robbins sebagaimana dikutip oleh Nair (2013:35) "QWL as a process by which an organization responds to employees needs by developing mechanisms to allow them to share fully in making the decisions their design their lives at work". Maksudnya adalah kualitas kehidupan kerja merupakan tanggapan organisasi terhadap keinginan karyawan dalam mekanisme pengembangan pada berbagai desain pengambilan keputusan karyawan di tempat kerja.

Davis sebagaimana dikutip oleh Carayon et al. (2003:59) "Quality of Work Life as the quality of the relationship between employees and the total working environment, with human dimensions added to the usual technical and economic considerations". Maksudnya adalah kualitas kehidupan kerja merupakan kualitas secara keseluruhan dalam hubungan antar karyawan dan lingkungan kerja, serta manusia dijadikan sebagai dimensi pada pertimbangan ekonomi dan teknikal. Dengan kata lain, hubungan antar karyawan dan lingkungan kerja yang aman dan menyenangkan 
karyawan dapat memberikan efek positif terhadap sikap dan perilakunya dalam melaksanakan pekerjaan. Karena itu, organisasi perlu menciptakan kondisi dan lingkungan kerja yang aman dan sehat serta menguntungkan karyawan. Hal ini juga di kemukakan oleh Islam dan Siengthai (2009:5) bahwa Kualitas kehidupan kerja adalah kondisi yang baik dan lingkungan yang menguntungkan karyawan, kesejahteraan karyawan, dan sikap manajemen terhadap operasional karyawan secara umum. Sejalan dengan ini, menurut Filippo (2005:45) mendefinisikan kualitas kehidupn kerja (quality of work life) sebagai setiap pekerjaan (perbaikan) yang terjadi pada setiap tingkatan dalam suatu organisasi untuk meningkatkan efektivitas organisasi yang lebih besar melalui peningkatan martabat dan pertumbuhan manusia.

Ivancevich, Konopaske, dan Matteson (2011:151) mendefinisikan kualitas kehidupan kerja (quality of work life) sebagai berikut: "Quality of work life is a philosophy of management that enhances the dignity of all workers; introduces changes in an organization's culture; and improves the physical and emotional wellbeing of employees (e.g., providing opportunities for growth and development)". Maksud definisi di atas adalah, bahwa Kualitas kehidupan kerja merupakan filosofi manajemen untuk meningkatkan martabat pekerja atau karyawan, memperkenalkan perubahan dalam budaya organisasi dan memperbaiki keadaan fisik dan psikis karyawan. Hal ini juga menunjukan bahwa, perubahan budaya organisasi dan menciptakan lingkungan kerja yang sehat dan aman akan berdampak terhadap kesehatan mental dan fisik karyawan. Artinya, lingkungan kerja yang sehat dan aman dapat memberikan motivasi atau dorongan kepada karyawan untuk bekerja lebih baik, sehingga tujuan organisasi dapat tercapai. Terkait dengan hal ini, menurut Rose sebagaimana dikutip oleh Naude (2010:23) bahwa, "kualitas kehidupan kerja adalah persepsi karyawan mengenai tempat kerja".

Sedangkan menurut Cascio (2006:65), quality of work life (QWL) dapat diartikan menjadi dua pandangan yaitu: pandangan pertama menyebutkan bahwa QWL merupakan sekumpulan keadaan dan praktek dari tujuan organisasi (contohnya: pemerkayaan pekerjaan, kebijakan promosi dari dalam, kepenyeliaan yang demokratis, partisipasi karyawan dan kondisi kerja yang nyaman). Pandangan kedua menyatakan bahwa QWL merupakan persepsi-persepsi karyawan seperti karyawan merasa aman, secara relatif merasa puas serta mendapatkan kesempatan tumbuh dan berkembang sebagai layaknya manusia.

Berdasarkan pendapat-pendapat di atas, menunjukan bahwa kualitas kehidupan kerja pada hakikatnya adalah usaha organisasi untuk menciptakan situasi lingkungan kerja yang memiliki efek terhadap pertumbuhan karyawan yang dapat dilakukan melalui faktor-faktor tertentu diantaranya adalah rasa keadilan, keterlibatan kerja, dan lain-lain. Karena itu, faktor-faktor yang akan dipersepsikan karyawan terkait dengan kualitas kehidupan kerjanya perlu diidentifikasi dan analisis oleh manajemen organisasi 
untuk menciptakan lingkungan kerja yang menguntungkan karyawan atau para pekerja. Artinya bahwa, pihak manajemen organisasi tidak hanya memperhatikan kepentingan organisasi, tetapi perlu juga untuk memperhatikan kepentingan karyawan, karena mereka merupakan modal organisasi untuk mencapai tujuan organisasi.

Terkait dengan faktor-faktor yang menentukan kualitas kehidupan kerja, berdasarkan berbagai studi literatur Taghavi, et al., (2014:297) mengemukakan bahwa faktor-faktor (ukuran) kualitas kehidupan kerja terdiri dari: hubungan tim (team relationships), lingkungan kerja yang sehat (healty working environment), dukungan sesama karyawan (fellow employees' support), kejelasan peran (role clarity), dan otoritas keputusan (decision authority).Pendapat lain dikemukakan oleh Walton sebagaimana dikutip oleh Sheel et al. (2012:294) "bahwa terdapat kriteria untuk meningkatkan Kualitas kehidupan kerja meliputi: (1) Kompensasi yang adil dan sesuai, yaitu terkait dengan keadilan dan keuntungan/manfaat kompensasi yang diperoleh memenuhi standar hidup pekerja. (2) Lingkungan kerja yang aman dan sehat, yaitu terkait dengan keamanan lingkungan kerja terhadap fisik dan psikis. (3) Menggembangkan kapasitas, yaitu terkait dengan otonomi kerja, diversitas kualitas kerja, dan informasi yang diperoleh ditempat kerja. (4) Pertumbuhan dan Jaminan kerja, yaitu terkait dengan potensi karir, pertumbuhan personal, dan jaminan kerja. (5) Integrasi sosial, yaitu terkait dengan absensi, persamaan hak dalam organisasi, mobilitas kerja, hubungan dengan orang lain, dan rasa kebersamaan. (6) Konstitusionalisasi, yaitu terkait dengan perlindungan hak, privasi personal, peraturanperaturan kerja, kebebasan berekspresi, dan perlakuan yang adil yang diperoleh didalam organisasi. (7) Pekerjaan dan ruang hidup secara keseluruhan, yaitu terkait dengan keseimbangan antara pekerjaan, keluarga dan kehidupan pribadi, seperti: Jaminan Kesejahteraan, kehidupan yang layak, dan waktu yang diluangkan untuk keluarga, dan (8) Relevansi sosial dalam kehidupan kerja, yaitu terkait dengan kesan organisasi, respon sosial organsiasi, dan respon organisasi terhadap hasil-hasil kerja.

Kriteria atau ukuran-ukuran kualitas kehidupan kerja ini, juga digunakan oleh Sajjad dan Abbasi (2013:95) yaitu: (1) Kompensasi yang adil dan sesuai (adequate and fair compensation); (2) Lingkungan kerja yang aman dan sehat (safe and healthy environment); (3) Penggunaan dan pengembangan kemampuan manusia (growth and security); (4) Pertumbuhan dan jaminan kerja (development of human capabilities); (5) Integrasi sosial (social integration); (6) Pekerja dan ruang hidup secara keseluruhan (the total life space), (7) Aturan kerja (constitutionalism), dan (8) Kesesuaian sosial dalam kehidupan kerja (social relevance).

\section{Kinerja Pegawai}

Kinerja selalu menjadi isu aktual dalam organisasi apapun bentuknya, karena kinerja merupakan kunci atau keberhasilan organisasi. Selain itu, kinerja juga 
merupakan sumber daya manusia yang harus direncanakan, dikelola, dan dievaluasi secara baik dan benar. Karena itu, karyawan dituntut secara individu untuk bekerja atau melaksanakan tugas secara konsisten sesuai dengan tugas daan tanggungjawabnya, sehingga dapat berkontribusi terhadap tujuan organisasi. Hal ini sebagaimana menurut Mangkunegara (2009:18), kinerja karyawan adalah hasil kerja secara kualitas dan kuantitas yang dicapai oleh seseorang pegawai dalam melaksanakan tugasnya sesuai dengan tanggung jawab yang diberikan kepadanya. Sejalan dengan hal ini, Hersey dan Blanchard dalam Dharmawan (2011:34) menerangkan bahwa kinerja merupakan suatu fungsi dari motivasi dan kemampuan untuk menyelesaikan tugas atau pekerjaan seseorang serta pemahaman yang jelas tentang apa yang akan dikerjakan dan bagaimana cara mengerjakannya.

Sedangkan Pengertian kinerja menurut Moeheriono (2012:95), yaitu Kinerja atau performance merupakan gambaran mengenai tingkat pencapaian pelaksanaan suatu program kegiatan atau kebijakan dalam mewujudkan sasaran, tujuan, visi dan misi organisasi yang dituangkan melalui perencanaan strategis suatu organisasi. Sementara itu, Menurut Amstrong (2009:31) kinerja adalah hasil pekerjaan yang mempunyai hubungan kuat dengan tujuan organisasi, kepuasan konsumen dan memberikan kontribusi ekonomi. Definisi ini melihat kinerja sebagai hasil, sementara kinerja perlu juga dilihat sebagai sebuah perilaku seorang individu, karena kaulitas maupun kuantitas yang dihasilkan seorang individu merupakan interaksi berbagai faktor pribadi yang mendukung tercapainya suatu hasil kerja.

Definisi kinerja di atas selain melihat kinerja karyawan sebagai suatu hasil, juga melihat kinerja sebagai perilaku individu. Artinya kinerja karyawan tidak hanya membutuhkan atau dilihat berdasarkan kualitas dan kuantitas kerja, tetapi juga memerlukan sikap dan perilaku kerja karyawan misalnya kemauan bekerja sama dengana orang lain, menghargai orang lain, dan lain-lain. Selain itu, dalam konteks hasil, Bernardin (2010:222) mendefinisikan kinerja sebagai berikut: "Performance is defined here as the record of outcomes produced on specified job fuctions or activities during a specified time periode". Maksud dari definisi ini adalah kinerja merupakan dokumentasi hasil-hasil seorang individu dari suatu pekerjaan yang sesuai dengan waktu yang ditentukan. Definisi tersebut belum melihat kinerja sebagai perilaku kerja. Namun demikian, hasil kerja perlu dikaitkan dengan karakteristik personal (misalnya: ketergantungan, integritas, ketekunan, pengetahuan, sikap, dan loyalitas) walaupun faktor tersebut bukan pengukuran kinerja aktual, tetapi turut menentukan kinerja secara keseluruhan (Bernardin, 2010:222). Dengan kata lain kinerja tidak hanya di ukur berdasarkan hasil kerja, tetapi juga didasarkan pada perilaku kerja.

Kinerja sebagai hasil dan perilaku juga dikemukakan oleh Campbell JP., (1990:33) bahwa: "believes that: Performance is behaviour and should be distinguished from the outcome because they can be contaminated by systems factors". Definisi ini tidak hanya melihat kinerja sebagai suatu hasil, tetapi kinerja juga merupakan perilaku yang 
perlu dibedakan, karena hasil dan perilaku kerja dapat dipengaruhi oleh faktor-faktor sistem organisasi. Pendapat lain yang mendukung pernyataan ini dikemukakan oleh Brumbach dalam Amstrong (2009:31) sebagai berikut:

"Performance means both behaviors and results. Behaviors emanate from the performer and transform performance from abstraction to action. No just the instruments for results, behaviors are also outcomes in their own right - the product of mental and physical effort applied to task - and can be judget apart from results".

Maksud dari pernyataan di atas, bahwa kinerja adalah perilaku dan hasil, dimana perilaku yang bersumber dari seorang individu ditranformasikan menjadi suatu tindakan dan selain itu, bahwasanya perilaku juga merupakan hasil yang dihasilkan secara psikis dan fisik untuk menghasilkan suatu hasil (performance).

Berkaitan dengan perilaku dan hasil di dalam Peraturan Pemerintah Nomor 46 Tahun 2011 pasal 1 ayat 3 mengartikan "kinerja sebagai hasil kerja yang dicapai oleh setiap PNS pada satuan organisasi sesuai dengan sasaran kerja pegawai dan perilaku kerja". Selanjutnya yang dimaksud dengan : "sasaran kerja pegawai yang selanjutnya disingkat dengan SKP adalah adalah rencana kerja dan target yang akan dicapai oleh seorang PNS, target adalah jumlah beban kerja yang akan di capai dari setiap pelaksanaan tugas jabatan, perilaku kerja adalah setiap tingkah laku, sikap atau tindakan yang dilakukan oleh PNS atau tidak melakukan sesuatu yang seharusnya dilakukan, sedangkan rencana kerja tahunan adalah rencana yang memuat kegiatan tahunan dan target yang akan dicapai sebagai penjabaran dari sasaran dan program yang telah ditetapkan oleh instansi pemerintah".

Untuk mengukur atau menilai kinerja karyawan dari sisi hasil dan perilakunya, setiap organisasi perlu menentukan standar atau ukuran-ukuran kinerja. Menurut Ivancevich (2010:261) bahwa ukuran atau indikator kinerja terdiri dari: (1) Quality of work terkait dengan volume pekerjaan yang dapat diterima dalam kondisi normal, (2) Quantity terkait dengan ketelitian, kerapian, dan ketepatan kerja, (3) Knowledge of job terkait dengan kemampuan menjelaskan maksud dari fakta atau faktor-faktor yang berkaitan dengan pekerjaan, (4) Personal qualities terkait dengan Kepribadian, penampilan, keramahan, kepemimpinan, dan integritas, (5) Cooperation terkait dengan Kemampuan dan kemauan untuk bekerja dengan rekan kerja, supervisor dan bawahannya menuju tujuan bersama, (6) kepercayaan (Depentability) terkait dengan bersungguh-sungguh, ketelitian, akurat, dapat diandalkan sehubungan dengan kehadiran, waktu makan siang, waktu istirahat, dan lain-lain, dan (7) Initiative terkait dengan kesungguhan dalam mencari tanggung jawab meningkat, memulai sendiri pekerjaan atau tidak takut untuk melanjutkan sendiri. Sejalan dengan pendapat ini, menurut Bernardin (2010:222) terdapat enam (6) indikator kinerja yaitu: (1) Quality: terkait dengan proses atau hasil mendekati sempurna/ideal memenuhi maksud atau tujuan, (2) Quantity: terkait dengan Jumlah produksi, dinyatakan dalam satuan tertentu atau jumlah siklus penyelesian kegiatan, (3) Timelines terkait dengan 
ketepatan waktu yang diperlukan dalam menyelesaikan suatu pekerjaan, atau tingkat dimana suatu kegiatan diselesaikan dalam jangka yang lebih cepat dari waktu yang ditetapkan dan memanfaatkan waktu yang tersedia untuk kegiatan lain, (4) Costeffectiveness terkait dengan tingkat penggunaan sumber-sumber organisasi (orang, uang, material, teknologi) dalam mendapatkan atau memperoleh hasil atau pengurangan pemborosan dalam pengunaan sumber-sumber organisasi, (5) Need for supervision terkait dengan kemampuan individu dapat menyelesaikan pekerjaan atau fungsi pekerjaan tanpa eksistensi pimpinan atau intervensi pengawasan pimpinan, dan (6) Interpersonal impact terkait dengan kemampuan individu dalam meningkatkan rasa harga diri (self-esteem), keinginan baik, dan kerja sama diantara sesama pekerja.

Indikator-indikator kinerja yang dikemukakan oleh kedua pakar di atas lebih menitikberatkan pada kualitas dan kuantitas pekerjaan yang dihasilkan karyawan sesuai dengan maksud dan tujuan organisasi. Jadi, pada hakikatnya kinerja karyawan berkontribusi positif terhadap tujuan organisasi, bila mana karyawan dapat menyelesaikan suatu pekerjaan baik dari sisi jumlah (quantity) maupun kualitas (quantity) memberikan manfaat kepada orang lain dan organisasi tempat ia bekerja. Untuk memperoleh kualitas dan jumlah pekerjaan seorang karyawan yang berarti, perlu diukur juga dengan menggunakan timelines yakni menyelesaikan suatu pekerjaan tepat pada waktunya. Selain itu, karyawan yang dapat memanfaatkan waktu luang untuk kegiatan lain untuk kebutuhan pekerjaan selalu disiplin atau loyal terhadap organisasi, dan dengan demikian waktu istirahat dan waktu makan siang selalu menjadi perhatian dan dimanfaatkan serta semua pekerjaannya dapat dipertanggungjawabkan (depentability) dengan baik. Ini juga berarti, seorang karyawan memiliki inisiatif (initiative) terhadap pekerjaannya yakni kesungguhan dalam mempertanggungjawabkan atas apa yang telah dikerjakannya. Karena itu, karyawan memerlukan pengetahuan atau dapat distilahkan dengan knowledge of job.Need for supervision secara eksplisit juga merupakan faktor yang turut menentukan kemampuan seorang karyawan menyelesaikan atau menghasilkan hasil kerja yang sesuai dengan tujuan organisasi, karena need for supervision merupakan kemampuan yang dimiliki karyawan dalam menjelaskan fakta-fakta pekerjaannya.

Selanjutnya, cost-efectiveness kaitannya dengan penggunaan sumber-sumber daya organisasi secara efektif dan efisien berhubungan dengan kualitas personal (personal qualities), karena personal qualities (misalnya kepribadian) seorang individu akan menentukan sikap ia di tempat kerja, khususnya pada saat memanfaatkan sumber-sumber daya organisasi. Kepribadian (personality) adalah seperangkat karakteristik yang mendasari suatu pola perilaku yang relatif stabil sebagai respon pada ide-ide, objek-objek, atau orang-orang didalam lingkungan (Daft, 2006:273). Ini berarti, keperibadian seperti keterbukaan (extroversion) yakni suatu tingkat dimana seseorang mudah bergaul, suka berbicara, tegas, dan merasa nyaman dengan hubungan antarperonal, menentukan kinerja baik dari sisi kualitas maupun jumlah 
pekerjaan. Interpersonal impac juga bagian dari perilaku terkait dengan kemampuan untuk mau bekerja sama dengan rekan kerja untuk melakukan suatu pekerjaan. Hal ini, sama seperti karyawan yang memiliki sifat kooperatif atau seorang yang memiliki sifat keramah-tamahan (agreablenes).

\section{Pengembangan Hipotesis}

Pengaruh Workplace Sprituality Terhadap Kinerja Perawat

Spritualitas ditempat kerja merupakan kesadaran individu atau orang di tempat kerja yang ditumbuhkan melalui pekerjaan yang bermakna yang berlangsung dalam konteks komunitas. Organisasi yang mendukung budaya spritualitas mengakui bahwa manusia memiliki pikiran dan jiwa, berusaha mencari makna dan tujuan dalam pekerjaan mereka, dan hasrat yang berhubungan dengan orang lain, serta menjadi bagian dari sebuah komunitas (Robbins dan Judge, 2008). Terkait dengan hal ini Ashmos dan Duchon (2000) bahwa pengakuan terhadap spiritualitas di tempat kerja berarti memandang tempat kerja sebagai suatu tempat yang dihuni oleh orang-orang yang memiliki pikiran (akal) dan semangat, dan meyakini pengembangan semangat adalah sama pentingnya dengan pengembangan pikiran.

Kedua pernyataan di atas menunjukan bahwa, spritualitas di tempat kerja merupakan suatu keadaan emosional individual yang dimanisfestasikan dalam pekerjaan yakni membangun kerja sama dengan orang lain untuk menemukan makna atau memahami bahwa kehidupan kerja di dalam organisasi adalah penting karena akan berpengaruh terhadap hasil-hasil kerja. Hal ini sebagaimana menurut Mitroff dan Denton (1999) dalam hakim dan Azlimin (2015:346) bahwa, spiritualitas di tempat kerja yaitu upaya untuk mencari dan menemukan makna tertinggi kehidupan untuk kehidupan kerja, untuk berkomunikasi antara individu dan rekan-rekan mereka serta orang-orang lain yang entah bagaimana berkontribusi terhadap pekerjaan, juga harmoni atau kesatuan antara individu percaya dengan nilai organisasi mereka. Dengan demikian, seorang karyawan yang memiliki spiritualitas di tempat kerjanya akan mampu meningkatkan kinerjanya yang pada akhirnya memberikan kontribusi positif terhadap kinerja organisasi.

Berdasarkan pendapat di atas, maka kinerja karyawan dapat ditingkatkan melalui spritualitas karyawan yakni, kemampuan dalam menemukan makna dalam kehidupan kerja yang dapat dilakukan melalui membangun komunikasi dan bekerja sama dengan orang lain di tempat kerjanya. Dengan kata lain, faktor-faktor dari spritualitas di tempat kerja yang terdiri dari, Meaningful work, sense of community, dan alignment of values (Milliman et al. 2003 dalam Amalia dan Yunizar, 2011:4) yang dimiliki oleh seorang karyawan akan memberikan kontribusi positif hasil dan perilaku kerja karyawan. Artinya, apabila seorang karyawan memiliki spritualitas di tempat kerja (workplace spirituality), maka hal itu akan memberikan kontribusi terhadap kinerja 
(performance). Karena, dengan adanya workplace spirituality seorang individu akan tetap berupaya untuk memaknai pekerjaannya yakni bekerja sama dengan karyawan atau orang lain secara baik, karena menganggap bahwa bekerja sama mampu menghasilkan kinerja yang baik.

Sebagaimana konsep kinerja karyawan yakni, suatu hasil-hasil dan perilaku kerja yang perlu dibedakan, karena hasil dan perilaku kerja dapat dipengaruhi oleh faktorfaktor sistem organisasi (Campbell JP, 1990:33), maka jelas bahwa, dengan adanya spiritualitas di tempat kerja, maka seorang karyawan termasuk para dokter selain menghasilkan pekerjaan yang sesuai dengan tujuan organisasi, mereka juga akan berperilaku baik untuk memenuhi kepentingan organisasi. Hal ini juga didukung oleh penelitian yang dilakukan oleh Pradhan, Panigrahy, dan Jena (2015:45) menyimpulkan bahwa, piritualitas di tempat kerja membantu karyawan di area kreativitas, perbaikan proses, layanan pelanggan, kejujuran dan kepercayaan, dan komitmen, yang pada akhirnya menyebabkan peningkatan Kinerja organisasi. Organisasi yang mendorong pengalaman spiritualitas meningkatkan kinerja organisasi dan profitabilitas dengan memberdayakan karyawan untuk menunjukkan keberagaman tugas dan non-tugas terkait perilaku. Hal ini memfasilitasi karyawan untuk menjadi lebih berkomitmen pada pekerjaan dan membantu mereka untuk perbaikan dan kemajuan organisasi. Hasil penelitian Petchsawanga dan Duchon (2012:200-202) rasa sayang (compassion), rasa perhatian (meaningfulness) perasaan bermakna (meaningful work), dan kelebihan beban kerja (transcendence) berpengaruh positif terhadap kinerja karyawan. Dengan demikian maka secara teoretik dapat disimpulkan bahwa, spiritualitas di tempat kerja berpengaruh positif dan signfikan terhadap kinerja karyawan atau kinerja dokter.

$H_{1}$ : Spiritualitas di tempat kerja berpengaruh positif dan signifikan terhadap Kinerja Perawat di RSUD dr. Chasan Boesoerie Provinsi Maluku Utara.

\section{Pengaruh Kualitas Kehidupan Kerja Terhadap Kinerja Perawat}

Pimpinan sebuah organisasi apapun bentuknya tidak hanya memikirkan kepentingan organisasi, tetapi juga perlu memikirkan kepentingan kayawannya atau brtanggungjawab atas keperluan karyawan yang didapat dilakukan melalui pengembangan sumber daya-sumber daya organisasi khususnya manusia dan menciptakan lingkungan kerja yang sehat dan aman. Organisasi perlu untuk menciptakan kualitas kehidupan kerja yang mampu mendorong karyawan bekerja dengan baik. Menurut Newstrom dan Davis (2002:244), kualitas kehidupan kerja adalah cara organisasi dimana mereka bertanggungjawab terhadap pengembangan dan kondisi kerja yang lebih baik (sehat dan aman) untuk pekerja, yang mana hal ini akan berpengaruh terhadap kesehatan ekonomi organisasi. Sedangkan menurut 
Greenberg dan Baron (2003:612) Kualitas kehidupan kerja merupakan teknik pengembangan organisasional dalam meningkatkan fungsi organisasi berkaitan dengan karyawan dalam mendapatkan perlakuan secara adil, demokratis dan karyawan dilibatkan dalam pengambilan keputusan ditempat kerja.

Uraian di atas menunjukan bahwa, kualitas kehidupan kerja yang dilakukan oleh organisasi dapat menumbuhkan semangat kerja karyawan untuk bekerja sesuai dengan tujuan organisasi. Karena itu, kualitas kehidupan kerja yang terdir dari: Kompensasi yang adil dan sesuai, Lingkungan kerja yang aman dan sehat, Menggembangkan kapasitas, Pertumbuhan dan Jaminan kerja, Integrasi sosial, Konstitusionalisasi, Pekerjaan dan ruang hidup secara keseluruhan, dan Relevansi sosial dalam kehidupan kerja (Walton sebagaimana dikutip oleh Sheel et al. 2012:294) akan menumbuhkan kinerja karyawan yang nantinya akan memberikan kontribusi terhadap kinerja organisasi. Hal ini sebagaimana menurut Amstrong (2009:31) kinerja karyawan adalah hasil pekerjaan yang mempunyai hubungan kuat dengan tujuan organisasi, kepuasan konsumen dan memberikan kontribusi ekonomi. Sejalan dengan ini, Brumbach dalam Amstrong (2009:31) kinerja karyawan adalah perilaku dan hasil, dimana perilaku yang bersumber dari seorang individu ditranformasikan menjadi suatu tindakan dan selain itu, bahwasanya perilaku juga merupakan hasil yang dihasilkan secara psikis dan fisik untuk menghasilkan suatu hasil (performance).

Dengan demikian, jelas bahwa kualitas kehidupan kerja yang dilakukan oleh organisasi untuk kepentingan karyawan, akan berpengaruh positif terhadap kinerja karyawan baik dari sisi hasil kerja maupun perilaku kerja. Hal juga telah dibuktikan dalam penelitian terdahulu yang dilakukan oleh Arifin (2012:17); Otiende (2014:32-34); dan Irawati (2015:51) menunjukan: kualitas kehidupan kerja (quality of work life) berpengaruh positif dan signifikan terhadap kinerja karyawan.

$\mathrm{H}_{2}$ : Kualitas Kehidupan kerja berpengaruh positif dan signifikan terhadap Kinerja Perawat di RSUD dr. Chasan Boesoerie Provinsi Maluku Utara.

\section{Pengaruh Workplace Spirituality Terhadap Kualitas Kehidupan Kerja}

Sebagaimana telah dijelaskan sebelumnya oleh Ashmos dan Duchon (2000) bahwa pengakuan terhadap spiritualitas di tempat kerja berarti memandang tempat kerja sebagai suatu tempat yang dihuni oleh orang-orang yang memiliki pikiran (akal) dan semangat, dan meyakini pengembangan semangat adalah sama pentingnya dengan pengembangan pikiran. Seangkan kualitas kehidupan kerja adalah cara organisasi dimana mereka bertanggungjawab terhadap pengembangan dan kondisi kerja yang lebih baik (sehat dan aman) untuk pekerja, yang mana hal ini akan berpengaruh terhadap kesehatan ekonomi organisasi (Newstrom dan Davis, 
2002:244). Dengan demikian, maka spirutualitas di tempat kerja selain berpengaruh terhadap kinerja karyawan, juga memiliki pengaruh terhadap kualitas kehidupan kerja.

Maksud dari urain di atas adalah seorang karyawan yang memiliki spritualitas di tempat kerja yakni: Meaningful work, sense of community, dan alignment of values (Milliman et al. 2003 dalam Amalia dan Yunizar, 2011:4), akan mampu menumbuhkan usaha organisasi dalam menciptakan kualitas kehidupan kerja. Artinya, kualitas kehidupan kerja tidak hanya menjadi tanggungjawab organisasi atau pimpinan organisasi, tetapi juga merupakan tanggung bersama antara pihak manajemen dan para karyawan.

Dengan demikian, jelas bahwa spiritualitas di tempat kerja secara teori mampu memberikan kontribusi positif terhadap kualitas kehidupan kerja. Hasil penelitian terdahulu membuktikan spritualitas di tempat kerja yang terdiri dari:Perasaan bermakna dalam pekerjaan (Meaningful work), Perasaan terhubung dengan komunitas (sense of community), dan Penegakan nilai-nilai (alignment of values) berpengaruh positif dan signifikan terhadap kualitas kehidupan kerja (Hojjati dan Hamidi, 2015:24).

$\mathrm{H}_{2}$ : Spiritualitas di tempat kerja berpengaruh positif dan signifikan terhadap Kualitas Kehidupan kerja di RSUD dr. Chasan Boesoerie Provinsi Maluku Utara.

\section{METODE PENELITIAN}

Desain Penelitian

Desain penelitian ini merupakan rencana yang menyeluruh langkah kerja penelitian, dari persiapan sampai penyelesaian laporan penelitian. Di dalamnya mencakup langkah kerja yang mengemukakan apa yang harus dilakukan oleh peneliti mulai pada saat dinyatakannya hipotesis penelitian sampai dengan analisis akhir dari data yang dikumpulkan.

Desain yang digunakan dalam penelitian ini adalah deskriptif-verifikatif dengan tujuan untuk menyajikan gambaran secara terstruktur, faktual dan akurat serta menguji hipotesis secara empirik. Dalam hal ini menggambarkan tentang spiritualitas di tempat kerja, kualitas kehidupan kerja dan kinerja pegawai.

\section{Populasi dan Sampel}

Populasi adalah wilayah generalisasi yang mempunyai kualitas dan karakteristik tertentu yang ditetapkan oeh peneliti yang dipelajari dan kemudian ditarik kesimpulannya. Sedangkan sampel adalah adalah jumlah yang dimiliki oleh populasi. Populasi dan sampel dalam penelitian ini adalah Perawat di RSUD dr. Chasan Boesoerie Provinsi Maluku Utara. Jumlah populasi dalam penelitian ini adalah 326 orang perawat.

Metode atau teknik penarikan sampel yang digunakan adalah random sampling yakni pengambilan sampel secara acak. Ukuran sampel secara keseluruhan dapat 
ditentukan dengan menggunakan rumus dari Taro Yamane atau Slovin dalam Ridwan dan Kuncoro (2008:50) sebagai berikut :

$n=\frac{N}{N \cdot d^{2}+1}$

$n=\frac{326}{0,815+1}$

$\mathrm{n}=180$ orang

Dengan demikian, sampel atau jumlah perawat yang dijadikan responden adalah sebanyak 180 orang.

\section{Operasionalisasi Variabel}

Variabel dalam penelitian ini terdiri variabel spiritualitas di tempat kerja dan kualitas kehidupan kerja (variabel independen) dan variabel kinerja perawat (variabel dependen) adalah sebagai spiritulaitas di tempat kerja (X1): Usaha organisasi untuk menemukan tujuan hidup, mengembangkan hubungan kemitraan, dan mempertahankan konsistensi antara keyakinan individu (karyawan) dengan nilai-nilai organisasi. Indikatornya: Perasaan bermakna dalam pekerjaan (Meaningful work); Perasaan terhubung dengan komunitas (sense of community); dan Penegakan nilainilai (alignment of values). Spiritulaitas di tempat kerja (X1): Usaha organisasi untuk menemukan tujuan hidup, mengembangkan hubungan kemitraan, dan mempertahankan konsistensi antara keyakinan individu (karyawan) dengan nilai-nilai organisasi. Indikatornya: Perasaan bermakna dalam pekerjaan (Meaningful work); Perasaan terhubung dengan komunitas (sense of community); Penegakan nilai-nilai (alignment of values). Kualitas kehidupan kerja (X2): usaha organisasi yang berorientasi pada lingkungan kerja secara keseluruhan yang dipersepsikan dan untuk kepentingan karyawan dan organisasi. Indikatormnya: Kompensasi yang memadai dan adil; Lingkungan kerja yang aman dan sehat; Pengembangan kapasitas; Pertumbuhan dan jaminan kerja; Integrasi sosial; Konstitusionalisasi; Pekerjaan dan ruang hidup secara keseluruhan; dan Relevansi sosial dalam kehidupan kerja.

\section{Model Analisis}

Menurut Bihrnstedt dalam Kusnendi (2008:1) analisis jalur (path analysis) adalah perluasan dari model regresi yang digunakan untuk menganalisis hubungan antar variabel dengan tujuan untuk mengetahui pengaruh langsung maupun pengaruh tidak langsung dari himpunan variabel bebas (eksogen) terhadap variabel terikat (endogen). Penelitian ini adalah deskriptif dan verifikatif yang dilaksanakan melalui pengumpulan data primer di lapangan, karena itu metode penelitian yang digunakan adalah metode survei penjelasan (explanatory survey method) yang bertujuan untuk mengumpulkan 
data yang dilakukan terhadap obyek di lapangan dengan mengambil sampel dari suatu populasi dan menggunakan kuesioner sebagai alat pengumpulan data yang utama.

Untuk menguji pengaruh antara variabel bebas dan terikat yakni pengaruh spritualitas di tempat kerja (workplace spirituality) dan kualitas kehidupan kerja (quality of work life) terhadap Kinerja perawat di RSUD dr. Chasan Boesoerie di Provinsi Maluku Utara, maka alat uji yang digunakan adalah analisis jalur (path analysis) dengan menggunakan program Linear Structural Relationship (LISREL).

\section{Uji Validitas dan Reliabilitas Instrumen}

Untuk menguji apakah instrumen yang digunakan memenuhi syarat-syarat alat ukur yang baik, sehingga mengahasilkan data yang sesuai dengan apa yang diukur. Sebelum data yang diperoleh digunakan untuk menghitung pengaruh variabel yang dihipotesiskan dilakukan uji validitas dan uji reliabilitas.

\section{Statistik Inferensial}

Analisis inferensial digunakan untuk menguji hipotesis dengan teknik analisis jalur (path analysis). Al Rasyid dalam Supardi (2013:273) menjelaskan analisis jalur bertujuan untuk menerangkan akibat langsung dan tidak langsung seperangkat variabel bebas dengan seperangkat variabel terikat. Adapun langkah-langkah kerja analisis jalur menurut Riduwan dan Kuncoro (2008:116-117) adalah: (1) Merumuskan hipotesis dan persamaan structural, (2) Menghitung koeefisien jalur yang didasarkan pada koefisien regresi, (3) Menghitung koefisien jalur secara simultan, (4) menghitung koefisien jalur secara individu, (5) Membuat kesimpulan.

Model analisis jalur (path analysis) terdapat 2 (dua) tipe variabel yaitu: (1) variabel exogenous yaitu semua variabel yang tidak ada penyebab-penyebab eksplisitnya atau dalam diagram tidak anak-anak panah yang menuju kearahnya, dan (2) variabel endigenous yaitu variabel yang mempunyai anak-anak panah menuju kearah variabel tersebut (Supardi, 2013:274). Signifikansi koefisien jalur dihitung dengan menggunakan nilai t-test untuk melakukan pengujian secara parsial dengan kriteria:

Jika thitung $>$ ttabel, maka $\mathrm{HO}$ ditolak dan Ha diterima.

Jika thitung $\leq$ ttabel, maka $\mathrm{HO}$ diterima dan Ha ditolak.

Selain itu, dengan model analisis jalur dapat juga diidentifikasi pengaruh langsung (direct effect) dan pengaruh tidak langsung (indirect effect).

\section{Hipotesis Statistik}

Berdasarkan hipotesis penelitian yang telah dirumuskan sebelumnya, maka hipotesis statistik dalam penelitian ini adalah:

Hipotesis Pertama 


\begin{tabular}{|c|c|c|}
\hline $\mathrm{HO}$ & : $\rho y X 1$ & $\leq 0$, artinya tidak terdapat pengaruh $\mathrm{X} 1$ terhadap $\mathrm{Y}$ \\
\hline $\mathrm{H} 1$ & : $\rho y X 1$ & $>0$, artinya terdapat perngaruh $X 1$ terhadap $Y$ \\
\hline \multicolumn{3}{|c|}{ Hipotesis Kedua } \\
\hline HO & : $\rho y X 2$ & $\leq 0$, artinya tidak terdapat pengaruh $X 2$ terhadap $Y$ \\
\hline $\mathrm{H} 1$ & : $\rho y X 2$ & $>0$, artinya terdapat perngaruh $X 2$ terhadap $Y$ \\
\hline \multicolumn{3}{|c|}{ Hipotesis Ketiga } \\
\hline $\mathrm{HO}$ & $\rho \times 2 \times 1$ & $\leq 0$, artinya tidak terdapat pengaruh $\mathrm{X} 1$ terhadap $\mathrm{X} 2$ \\
\hline $\mathrm{H} 1$ & $\rho \times 2 \times 1$ & $>0$, artinya terdapat perngaruh $\mathrm{X} 1$ terhadap $\mathrm{X} 2$ \\
\hline
\end{tabular}

\section{HASIL PENELITIAN DAN PEMBAHASAN}

Uji Kecocokan Model Struktural

Pengujian ini dilakukan untuk mengetahui apakah model yang diperoleh telah tepat dalam menggambarkan hubungan antar variabel yang sedang diteliti sehingga dapat dikategorikan kedalam model yang baik (good fit). Berdasarkan output lisrel, pengujian kecocokan model secara keseluruhan (overall) menggunakan uji X2 (chisquare) diperoleh nilai $p$-value $=1,000<0,05$. Berdasarkan hasil uji $\chi 2$ maka model yang diperoleh secara keseluruhan fit (memiliki kecocokan model yang baik). Pengujian selanjutnya adalah Root Mean Square Error of Approximation (RMSEA) dimana hasil uji menunjukan RMSEA lebih kecil dari 0,08 atau RMSEA $=0,000<0,08$. Ini berarti bawa model memiliki kecocokan yang baik (good fit).

Hasil uji kecocokoan model (goodness of fit) dalam analisis jalur di atas, maka dapat dirangkum pada Tabel 1 berikut ini.

Tabel 1

Ringkasan Hasil Uji Kesesuaian Model

\begin{tabular}{cccc}
\hline Indeks & Hasil & Kriteria Uji & Kesimpulan \\
\hline Chi Square & 0,000 & $>0,05$ & Marginal Fit \\
\hline P Value & 1,000 & $<5$ & Good fit \\
\hline RMSEA & 0,000 & $\leq 0,08$ & Good fit \\
\hline
\end{tabular}

Sumber :Data diolah, 2018

Berdasarkan uraian di atas, maka dapat disimpulkan bahwa secara keseluruhan model struktural dalam penelitian ini memiliki kecocokam model yang baik (goodness of fit).

\section{Uji Persamaan Struktral}

Model struktural terdiri atas dua sub struktur yaitu sub struktur I (pertama) adalah pengaruh langsung spritualitas di tempat kerja dan Kualitas Kehidupan Kerja terhadap Kinerja perawat dan sub struktur II (kedua) adalah pengaruh langsung spritualitas di tempat kerja terhadap kualitas kehidupan kerja. Berdasarkan hasil 
pengolahan data menggunakan software Lisrel diperoleh persamaan struktural sub struktur I sebagai berikut:

$$
Y=0.490 * X 1+0.156 * X 2, \text { Errorvar. }=19.701, R^{2}=0.419
$$

Persamaan struktural di atas menunjukan bahwa besarnya pengaruh langsung spritualitas di tempat kerja dan kualtas kehidupan kerja secara parsial terhadap Kinerja perawat berturut-turut adalah 0,490, dan 0,156, sedangkan secara simultan adalah sebesar $41,90 \%$. Selain itu, spritualitas di tempat kerja memiliki pengaruh lebih dominan dari kualitas kehidupan kerja. Sedangkan, berdasarkan hasil pengolahan data menggunakan software Lisrel diperoleh persamaan struktural sub struktur II sebagai berikut:

$$
\mathrm{X} 2=0.405^{*} \mathrm{X} 1, \text { Errorvar. }=32.315, \mathrm{R}^{2}=0.182
$$

Persamaan struktural di atas menunjukan bahwa besarnya pengaruh langsung sprituaitas di tempat kerja secara parsial terhadap kualitas kehidupan kerja adalah sebesar 0,405. Secara keseluruhan diagram jalur standardized solution pada masingmasing variabel melalui program Lisrel versi 8.80 digambarkan sebagai berikut.

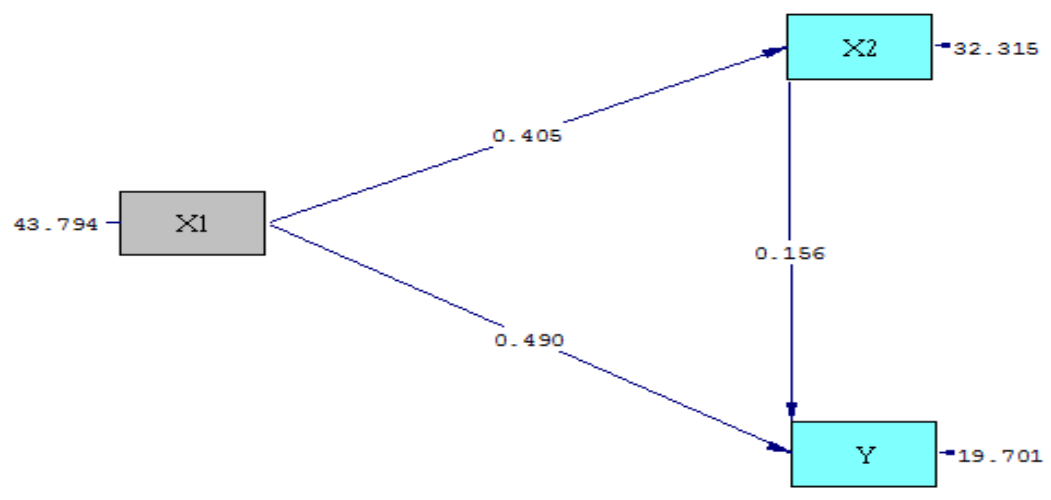

Gambar 1. Diagram Jalur Estimates Pengaruh Variabel Eksogen Terhadap Variabel Endogen

Berdasarkan gambar 1 (hasil estimasi diagram jalur) menunjukan adanya pengaruh langsung (direct) dan tidak langsung (indirect), serta totak pengaruh antar variabel eksogen $(\mathrm{X})$ dengan variabel endogen $(\mathrm{Y})$. Berdasarkan output lisrel tentang total dan indirect effect menunjukan bahwa: (1) nilai total pengaruh (total effect) variabel spiritualitas (X1) dan kualitas kehidupan kerja(X2) terhadap kinerja sama 
dengan nilai pengaruh langsung (direct effect) masing-masing variabel tersebut, karena tidak dimediasi oleh variabel lain (variabel intervening), dan (2) pengaruh tidak langsung (indirect effect) variabel spiritualitas (X1) terhadap kinerja $(\mathrm{Y})$ sebesar $0,405 \mathrm{x}$ $0,156=0,063$, karena adanya variabel lain (variabel intervening) yaitu kualitas kehidupan kerja (X2) sebesar 0,156 , sedangkan total pengaruhnya adalah sebesar $0,063+0,490=0,553$.

Uraian tentang total pengaruh variabel eksogen $(X)$ terhadap variabel endogen (Y) di atas menunjukan bahwa, variabel $\mathrm{X} 1$ dan $\mathrm{X} 2$ berpengaruh positif terhadap $\mathrm{Y}$ karena adanya intervening (mediasi) variabel $\mathrm{X} 2$, memiliki nilai pengaruh yang lebih besar dibandingkan dengan variabel yang tidak dimediasi oleh variabel lain. Dengan kata lain, spiritualitas dan kualitas kehidupan kerja bersama-sama mempengaruhi Kinerja memiliki nilai pengaruh yang lebih besar dibandingkan dengan hanya satu variabel eksogen $(\mathrm{X})$ yang mempengaruhi kinerja perawat.

\section{Pengujian Hipotesis}

Pengaruh Spritualitas di Tempat Kerja Terhadap Kinerja Perawat.

Pengujian hipotesis berdasarkan hasil perhitungan koefisien jalur dan thitung dengan menggunakan program lisrel 8.80 sebagaimana disajikan pada Tabel 2 di bawah ini:

Tabel 2

Hasil Pengujian Pengaruh Positif Spritualitas di Tempat Kerja Terhadap Kinerja Perawat

\begin{tabular}{cccc}
\hline Sampel & Koefisien Jalur $(\boldsymbol{\gamma y 2 \times 1 )}$ & Thitung & ttabel $(\boldsymbol{\alpha}=\mathbf{0 , 0 5})$ \\
\hline 180 & 0,490 & $8,041^{*}$ & 1,96 \\
\hline
\end{tabular}

Keterangan:

*Koefisien jalur signifikan, thitung=3,421 > ttabel=1,96.

Berdasarkan hasil pengujian pada tabel di atas menunjukan koefisien jalur variabel spritualitas di tempat kerja terhadap kinerja peraway $(\rho y X 1)=0,490$ yang memiliki nilai thitung $=8,4041$ lebih besar dari nilai ttabel $(\alpha=0,05)=1,96$. Karena thitung>ttabel, maka Ho ditolak yang berarti bahwa terdapat pengaruh positif spritualitas di tempat kerja terhadap kinerja perawat di RSUD dr. Chasan Boesoerie Provinsi Maluku Utara. Secara langsung spritualitas di tempat kerja memberikan pengaruh sebesar $(0,490) 2 \times 100 \%=24 \%$ terhadap kinerja perawat. Hasil penelitian ini memberikan bukti empiris bahwa spritualitas di tempat kerja mampu menciptakan atau meningkatkan kinerja perawat di RSUD dr. Chasan Boesoerie Provinsi Maluku Utara. 
Terdapat Pengaruh Kualitas Kehidupan Kerja Terhadap Kinerja Perawat.

Pengujian hipotesis berdasarkan hasil perhitungan koefisien jalur dan thitung dengan menggunakan program lisrel 8.80 sebagaimana disajikan pada Tabel 3 di bawah ini:

Tabel 3

Hasil Pengujian Pengaruh Positif Spritualitas di Tempat KerjaTerhadap Kinerja Perawat

\begin{tabular}{cccc}
\hline Sampel & Koefisien Jalur $(\gamma y 2 \times 1)$ & thitung & ttabel $(\alpha=0,05)$ \\
\hline 180 & 0,156 & $2,423^{*}$ & 1,96
\end{tabular}

Keterangan:

*Koefisien jalur signifikan, thitung=3,421 >ttabel=1,96.

Berdasarkan hasil pengujian pada tabel di atas menunjukan koefisien jalur variabel spritualitas di tempat kerja terhadap kinerja peraway $(\rho y \times 2)=0,156$ yang memiliki nilai thitung $=2,423$ lebih besar dari nilai ttabel $(\alpha=0,05)=1,96$. Karena thitung>ttabel, maka Ho ditolak yang berarti bahwa terdapat pengaruh positif kualitas kehidupan kerja (quality of work life) terhadap kinerja perawat di RSUD dr. Chasan Boesoerie Provinsi Maluku Utara. Secara langsung spritualitas di tempat kerja memberikan pengaruh sebesar $(0,490) 2 \times 100 \%=2,433 \%$ terhadap kinerja perawat. Hasil penelitian ini memberikan bukti empiris bahwa kualitas kehidupan kerja (quality of work life) mampu menciptakan kinerja perawat di RSUD dr. Chasan Boesoerie Provinsi Maluku Utara.

Pengaruh Spritualitas di Tempat Kerja Terhadap Kualitas Kehidupan Kerja.

Pengujian hipotesis berdasarkan hasil perhitungan koefisien jalur dan thitung dengan menggunakan program lisrel 8.80 sebagaimana disajikan pada tabel 4 di bawah ini:

Tabel 4

Hasil Pengujian Pengaruh Positif Spritualitas di Tempat Kerja Terhadap Kinerja Perawat

\begin{tabular}{cccc}
\hline Sampel & Koefisien Jalur $(\mathbf{\gamma y 2 \times 1 )}$ & thitung & ttabel $(\alpha=0,05)$ \\
\hline $\mathbf{1 8 0}$ & 0,405 & $5,739^{*}$ & 1,96 \\
\hline
\end{tabular}

Keterangan: *Koefisien jalur signifikan, thitung=3,421 > ttabel=1,96.

Berdasarkan hasil pengujian pada tabel di atas menunjukan koefisien jalur variabel spritualitas di tempat kerja terhadap kinerja peraway $(\rho \times 1 \times 2)=0,405$ yang memiliki nilai thitung $=2,423$ lebih besar dari nilai ttabel $(\alpha=0,05)=1,96$. Karena thitung>ttabel, maka Ho ditolak yang berarti bahwa terdapat pengaruh positif 
spritualitas di tempat kerja terhadap kualitas kehidupan kerja (quality of work life) di RSUD dr. Chasan Boesoerie Provinsi Maluku Utara. Secara langsung spritualitas di tempat kerja memberikan pengaruh sebesar $(0,405) 2 \times 100 \%=16,402 \%$ terhadap kualitas kehidupan kerja (quality of work life). Hasil penelitian ini memberikan bukti empiris bahwa spiritualitas di tempat kerja mampu menciptakan kualitas kehidupan kerja (quality of work life) di RSUD dr. Chasan Boesoerie Provinsi Maluku Utara.

\section{Pembahasan}

\section{Pengaruh Workplace Spirituality Terhadap Kinerja Perawat}

Hasil pengujian hipotesis pertama menunjukan bahwa spritualitas di tempat kerja berpengaruh positif terhadap kinerja perawat di RSUD dr. Chasan Boesoerie Provinsi Maluku Utara. Hasil ini menunjukan bahwa spritualitas di tempat kerja mampu menciptakan atau meningkatkan kinerja perawat di RSUD dr. Chasan Boesoerie Provinsi Maluku Utara.

Hasil pengujian ini berdasarkan nilai thitung X1 sebesar 8,4041 yang lebih besar dari nilai ttabel sebesar 1,96. Selain itu, sebelumnya telah dideskripsikan secara keseluruhan bahwa para perawat di Rumah Sakit telah melakukan penilaian melalui kuesioner terkait dengan spritualitas di tempat kerja. Penilaian atau tanggapan perawat berdasarkan pada indikator Perasaan bermakna dalam pekerjaan (Meaningful work), Perasaan terhubung dengan komunitas (sense of community), dan Penegakan nilai-nilai (alignment of values).

Secara keseluruhan total skor hasil tanggapan menunjukan bahwa nilai rata-rata skor variabel Workplace Sprituality (X1) sebesar 3,67 menunjukan bahwa seluruh item pernyataan pada variabel ini masuk dalam kategori baik atau tinggi. Dalam perspektif konseptual atau teori hal tersebut mengandung makna bahwa, Perasaan bermakna dalam pekerjaan (Meaningful work), Perasaan terhubung dengan komunitas (sense of community), dan Penegakan nilai-nilai (alignment of values) mampu menumbuhkan atau menciptakan kinerja perawat. Denga kata lain, faktor-faktor spritualitas di tempat kerja memberikan kontribusi positif terhadap kinerja perawat di RSUD dr. Chasan Boesoerie Provinsi Maluku Utara. Hasil penelitian ini relevan dengan pendapat yang dikemukakan oleh Robbins dan Judge (2011:529) bahwa, spritualitas ditempat kerja adalah kesadaran bahwa orang memiliki kehidupan batin yang tumbuh dan ditumbuhkan oleh pekerjaan yang bermakna yang berlangsung dalam konteks komunitas. Lebih lanjut dijelaskan bahwa, organisasi yang mendukung budaya spritualitas mengakui bahwa manusia memiliki pikiran dan jiwa, berusaha mencari makna dan tujuan dalam pekerjaan mereka, dan hasrat yang berhubungan dengan orang lain, serta menjadi bagian dari sebuah komunitas. Ini berarti spritualitas yang dimiliki oleh perawat mampu mendorongnya untuk melaksanakan tugas demi kepentingan organisasi RSUD. 
Uraian di atas menunjukan bahwa spritualitas di tempat kerja terkait dengan orang atau individu ditempat kerja yang saling memerlukan atau adanya rasa solidaritas sesama manusia atau anggota organisasi. Hal ini sebagaimana menurut Gibbons (2001) dalam hakim dan Azlimin (2015:346) bahwa, spiritualitas di tempat kerja termasuk konsep integritas dan solidaritas dalam bekerja dan memahami nilainilai yang mendalam dalam pekerjaan. Sementara itu menurut Mitroff dan Denton (1999) dalam hakim dan Azlimin (2015:346) bahwa, spiritualitas di tempat kerja yaitu upaya untuk mencari dan menemukan makna tertinggi kehidupan untuk kehidupan kerja, untuk berkomunikasi antara individu dan rekan-rekan mereka serta orang-orang lain yang entah bagaimana berkontribusi terhadap pekerjaan, juga harmoni atau kesatuan antara kepercayaan individu dengan nilai organisasi mereka. Kinjerski dan Skrypnek 2004 dalam hakim dan Azlimin (2015:346) spiritualitas di tempat kerja adalah pengalaman yang berbeda dicirikan oleh fitur kognitif, dimensi interpersonal, kehadiran spiritual, dan komponen mistis. Jadi, jelas bahwa spritualitas di tempat kerja merupakan faktor yang secara langsung mempengaruhi kinerja perawat di RSUD dr. Chasan Boesoerie.

Dengan demikian kinerja perawat dapat ditingkatkan melalui spritualitas karyawan yakni, kemampuan dalam menemukan makna dalam kehidupan kerja yang dapat dilakukan melalui membangun komunikasi dan bekerja sama dengan orang lain di tempat kerjanya. Dengan kata lain, faktor-faktor dari spritualitas di tempat kerja yang terdiri dari, Meaningful work, sense of community, dan alignment of values (Milliman et al. 2003 dalam Amalia dan Yunizar, 2011:4) yang dimiliki oleh seorang karyawan akan memberikan kontribusi positif hasil dan perilaku kerja karyawan/perawat. Artinya, apabila seorang karyawan memiliki spritualitas di tempat kerja (workplace spirituality), maka hal itu akan memberikan kontribusi terhadap kinerja (performance). Karena, dengan adanya workplace spirituality seorang individu akan tetap berupaya untuk memaknai pekerjaannya yakni bekerja sama dengan karyawan atau orang lain secara baik, karena menganggap bahwa bekerja sama mampu menghasilkan kinerja yang baik.

Berdasarkan pada distribusi tanggapan responden terhadap variabel spiritualitas seluruh item yang masuk dalam variabel ini masuk dalam kategori baik atau tinggi, ini dapat dilihat dari nilai rata-rata skor yang diperoleh yaitu sebesar 3,67. Meskipun demikian, terdapat beberapa hal yang perlu diperhatikan oleh RSUD dr. Chasan Boesoeirie Provinsi Maluku Utara adalah: 1) menciptakan lingkungan kerja yang memadai, 2) memberikan motivasi kepada perawat melalui pelatihan-pelatihan diantaranya adalah in the job trainning, 3) memberikan kesempatan kepada perawat untuk mengevaluasi kembali hasil penilaian pekerjaannya, dan 4) memberikan pemahaman kepada para perawat tentang visi, miisi, dan tujuan organisasi secara rinci. Hal ini dapat dilakukan melalui workshop, atau pertemuan-pertemuan resmi yang terprogram. 
Berdasarkan uraian-uraian di atas, maka dapat disimpulkan bahwa spritualitas secara parsial berpengaruh positif dan signifikan terhadap kinerja perawat dapat dibuktikan dalam penelitian ini baik secara teori maupun fakta-fakta yang ditemukan dan telah analisis. Selain itu, hasil penelitian ini mampu membuktikan kembali penelitian-penelitian yang dilakukan sebelumnya diantaranya adalah: (1) Javanmard(2012:1964) menunjukan bahwa spiritualitas (spirituality) di tempat kerja yang terdiri dari: makna dan tujuan hidup (inner life), meaning full at work, sense of communitberpengaruh kinerja karyawan; dan (2) Petchsawanga Duchon (2012:200202) menggunakan model regresi linear berganda menunjukan bahwa, spiritualitas di tempat kerja (workplace spirituality) berpengaruh positif terhadap kinerja karyawan dan Praktek meditasi (meditation practice).

\section{Pengaruh Kualitas Kehidupan Kerja Terhadap Kinerja Perawat}

Hasil pengujian hipotesis Kedua menunjukan bahwa kualitas kehidupan kerja berpengaruh positif terhadap kinerja perawat di RSUD dr. Chasan Boesoerie Provinsi Maluku Utara. Hasil ini menunjukan bahwa kualitas kehidupan kerja mampu menciptakan atau meningkatkan kinerja perawat di RSUD dr. Chasan Boesoerie Provinsi Maluku Utara.

Hasil pengujian ini berdasarkan nilai thitung X1 sebesar 2,423 yang lebih besar dari nilai ttabel sebesar 1,96. Selain itu, sebelumnya telah dideskripsikan secara keseluruhan bahwa para perawat di Rumah Sakit telah melakukan penilaian melalui kuesioner terkait dengan kulaitas kehiduan kerja. Penilaian atau tanggapan perawat berdasarkan pada indikator: Kompensasi yang adil dan sesuai, Lingkungan kerja yang aman dan sehat, Menggembangkan kapasitas, Pertumbuhan dan Jaminan kerja, Integrasi sosial, Konstitusionalisasi, Pekerjaan dan ruang hidup secara keseluruhan, dan Relevansi sosial dalam kehidupan kerja.

Secara keseluruhan total skor hasil tanggapan menunjukan bahwa nilai rata-rata skor variabel kualitas kehidupan kerja (X2) sebesar 3,64 menunjukan bahwa seluruh item pernyataan pada variabel ini masuk dalam kategori baik atau tinggi. Dalam perspektif konseptual atau teori hal tersebut mengandung makna bahwa, indikatorindikator kualitas kehidupan kerja mampu menumbuhkan atau menciptakan kinerja perawat. Hasil penelitian ini relevan dengan pendapat yang dikemukakan oleh Newstrom dan Davis (2002:244), kualitas kehidupan kerja adalah cara organisasi dimana mereka bertanggung jawab terhadap pengembangan dan kondisi kerja yang lebih baik (sehat dan aman) untuk pekerja, yang mana hal ini akan berpengaruh terhadap kesehatan ekonomi organisasi. Jadi, jelas bahwa kualitas kehidupan kerja merupakan salah satu faktor yang perlu menjadi perhatian organisasi untuk memfasilitas karyawan dalam melaksanakan tugas. 
Uraian di atas menunjukan bahwa, kualitas kehidupan kerja yang dilakukan oleh organisasi dapat menumbuhkan semangat kerja karyawan untuk bekerja sesuai dengan tujuan organisasi. Karena itu, kualitas kehidupan kerja yang terdir dari: Kompensasi yang adil dan sesuai, Lingkungan kerja yang aman dan sehat, Menggembangkan kapasitas, Pertumbuhan dan Jaminan kerja, Integrasi sosial, Konstitusionalisasi, Pekerjaan dan ruang hidup secara keseluruhan, dan Relevansi sosial dalam kehidupan kerja (Walton sebagaimana dikutip oleh Sheel, et al., 2012:294) akan menumbuhkan kinerja karyawan yang nantinya akan memberikan kontribusi terhadap kinerja organisasi. Hal ini sebagaimana menurut Amstrong (2009:31) kinerja karyawan adalah hasil pekerjaan yang mempunyai hubungan kuat dengan tujuan organisasi, kepuasan konsumen dan memberikan kontribusi ekonomi. Sejalan dengan ini, Brumbach dalam Amstrong (2009:31) kinerja karyawan adalah perilaku dan hasil, dimana perilaku yang bersumber dari seorang individu ditranformasikan menjadi suatu tindakan dan selain itu, bahwasanya perilaku juga merupakan hasil yang dihasilkan secara psikis dan fisik untuk menghasilkan suatu hasil (performance). Dengan demikian, jelas bahwa kualitas kehidupan kerja yang dilakukan oleh organisasi untuk kepentingan karyawan, akan berpengaruh positif terhadap kinerja karyawan baik dari sisi hasil kerja maupun perilaku kerja.

Berdasarkan pada distribusi tanggapan responden terhadap variabel kualitas kehidupan kerja seluruh item yang masuk dalam variabel ini masuk dalam kategori baik atau tinggi, ini dapat dilihat dari nilai rata-rata skor yang diperoleh yaitu sebesar 3,64. Meskipun demikian, terdapat beberapa hal yang perlu diperhatikan oleh RSUD dr. Chasan Boesoeirie Provinsi Maluku Utara adalah: 1) merumuskan kembali sistem kompensasi berdasarkan peraturan yang berlaku, dan mengimplementasikannya secara konsisten. Kompensasi yang dimaksud terdiri dari: Kompensasi langsung maupun kompensasi tidak langsung; 2) menciptakan lingkungan kerja yang aman dan bersih; 3) memberikan kesempatan kepada para perawat untuk mengembangkan diri. Hal ini dapat dilakukan dengan menyelenggarakan Diklat Teknis sesuai dengann bidang tugas masing-masing perawat; 4) memberdayakan perawat secara adil dan memberikan umpan balik atau respon atas berbagai keluhan para perawat; 5) merumuskan SOP disetiap unit RSUD dan mensosialisasikannya kepada perawat; dan 6) mengidentifikasi dan menyediakan fasilitas kerja sesuai dengan kebutuhan perawat di seluruh unit RSUD.

Berdasar berbagai uraian di atas, maka disimpulkan bahwa kualitas kehidupan kerja (quality of work life) secara parsial berpengaruh positif dan signifikan terhadap kinerja perawat dapat dibuktikan dalam penelitian ini baik secara teori maupun faktafakta yang ditemukan dan telah analisis. Selain itu, Penelitian ini sejalan dengan peneltian yang dilakukan oleh: (1) Arifin (2012:17) menunjukan bahwa, kualitas kehidupan kerja (quality of work life) berpengaruh positif dan signifikan terhadap kinerja karyawan; 2) menunjukan bahwa, Otiende (2014:32-34) kualitas kehidupan 
kerja berpengaruh positif dan signifikan terhadap kinerja tugas; 3) Parmin (2014: 102103) menunjukan bahwa, kualitas kehidupan kerja pengaruh positif kinerja perawat PD BPR BKK; dan 4) Irawati (2015:51) menunjukan bahwa, kualitas kehidupan kerja berpengaruh signifikan dan positif terhadap Kinerja Perawat.

\section{Pengaruh Workplace Spirituality Terhadap Kualitas Kehidupan Kerja}

Hasil pengujian hipotesis ketiga menunjukan bahwa spritualitas di tempat kerja berpengaruh positif terhadap kualitas kehidupan kerja di RSUD dr. Chasan Boesoerie Provinsi Maluku Utara. Hasil ini menunjukan bahwa spritualitas di tempat kerja mampu menciptakan kualitas kehidupan kerja (quality of work life) di RSUD dr. Chasan Boesoerie Provinsi Maluku Utara.

Hasil pengujian ini berdasarkan nilai thitung X1 sebesar 2,423 yang lebih besar dari nilai ttabel sebesar 1,96. Selain itu, sebelumnya telah dideskripsikan secara keseluruhan bahwa para perawat di Rumah Sakit telah melakukan penilaian melalui kuesioner terkait dengan spritualitas di tempat kerja. Penilaian atau tanggapan perawat berdasarkan pada indikator Perasaan bermakna dalam pekerjaan (Meaningful work), Perasaan terhubung dengan komunitas (sense of community), dan Penegakan nilai-nilai (alignment of values).

Secara keseluruhan total skor hasil tanggapan menunjukan bahwa nilai rata-rata skor variabel Workplace Sprituality (X1) sebesar 3,67 menunjukan bahwa seluruh item pernyataan pada variabel ini masuk dalam kategori baik atau tinggi. Dalam perspektif konseptual atau teori hal tersebut mengandung makna bahwa, Perasaan bermakna dalam pekerjaan (Meaningful work), Perasaan terhubung dengan komunitas (sense of community), dan Penegakan nilai-nilai (alignment of values) selain mempengaruhi atau menghasilkan kinerja perawat, juga mampu menciptakan kualitas kehidupaan kerja. Denga kata lain, faktor-faktor spritualitas di tempat kerja memberikan kontribusi positif terhadap kualitas kehidupan kerja perawat di RSUD dr. Chasan Boesoerie Provinsi Maluku Utara.

Ashmos dan Duchon (2000) mengemukakan bahwa pengakuan terhadap spiritualitas di tempat kerja berarti memandang tempat kerja sebagai suatu tempat yang dihuni oleh orang-orang yang memiliki pikiran (akal) dan semangat, dan meyakini pengembangan semangat adalah sama pentingnya dengan pengembangan pikiran. Seangkan kualitas kehidupan kerja adalah cara organisasi dimana mereka bertanggungjawab terhadap pengembangan dan kondisi kerja yang lebih baik (sehat dan aman) untuk pekerja, yang mana hal ini akan berpengaruh terhadap kesehatan ekonomi organisasi (Newstrom dan Davis, 2002:244). Dengan demikian, maka spirutualitas di tempat kerja selain berpengaruh terhadap kinerja karyawan, juga memiliki pengaruh terhadap kualitas kehidupan kerja. 
Maksud dari urain di atas adalah seorang karyawan yang memiliki spritualitas di tempat kerja yakni: Meaningful work, sense of community, dan alignment of values (Milliman et al. 2003 dalam Amalia dan Yunizar, 2011:4), akan mampu menumbuhkan usaha organisasi dalam menciptakan kualitas kehidupan kerja. Dengan demikian, kualitas kehidupan kerja tidak hanya menjadi tanggungjawab organisasi atau pimpinan organisasi, tetapi juga merupakan tanggung jawab bersama antara pihak manajemen dan para karyawan.

Berdasarkan pada distribusi tanggapan responden terhadap variabel spiritualitas seluruh item yang masuk dalam variabel ini masuk dalam kategori baik atau tinggi, ini dapat dilihat dari nilai rata-rata skor yang diperoleh yaitu sebesar 3,67. Karena itu, organisasi RSUD dr. Chasan Boesoerie dapat melakukan hal yang sama sebagaimana hal/cara yang dilakukan atau direkomendasikan pada deskripsi tentang "pengaruh spritualitas terhadap kinerja perawat. Artinya, bahwa dengan melakukan peningkatan kinerja perawat melaui spritualitas kerja, maka hal tersebut juga mempengaruhi secara langsung kualitas kehidupan kerja. Hal ini sebagaimana telah dibuktikan dalam penelitian ini bahwa, spritualitas di tempat kerja berpengaruh positif terhadap kualitas kehidupan kerja di RSUD dr. Chasan Boesoerie Provinsi Maluku Utara.

Berdasarkan uraian-uraian di atas, maka dapat disimpulkan bahwa spritualitas secara parsial berpengaruh positif dan signifikan terhadap kinerja perawat dapat dibuktikan dalam penelitian ini baik secara teori maupun fakta-fakta yang ditemukan dan telah analisis. Selain itu, hasil penelitian relevan dengan hasil penelitian yang dilakukan oleh Hojjati dan Hamidi (2015:24) menunjukan bahwa spritualitas kehidupan kerja yang terdiri dari: Perasaan bermakna dalam pekerjaan (Meaningful work), Perasaan terhubung dengan komunitas (sense of community), dan Penegakan nilainilai (alignment of values) berpengaruh positif dan signifikan terhadap kualitas kehidupan kerja (quality of work life).

\section{KESIMPULAN DAN SARAN}

\section{Kesimpulan}

Berdasarkan pada analisis penelitian dan pembahasan di atas, maka kesimpulan dalam penelitian ini adalah:

1. Workplace spirituality berpengaruh positif dan signifikan terhadap kinerja perawat. Ini berarti bahwa semakin tinggi work spirituality menyebabkan meningkatnya kinerja perawat di RSUD dr. Chasan Boesoeirie;

2. Kualitas kehidupan kerja berpengaruh positif dan signifikan terhadap kinerja perawat. Ini berarti bahwa semakin tinggi kualitas kehidupan kerja menyebabkan meningkatnya kinerja perawat di RSUD dr. Chasan Boesoeirie Provinsi Maluku Utara; 
3. Workplace Spirituality berpengaruh positif dan signifikan terhadap kualitas kehidupan kerja. Ini berarti bahwa semakin tinggi workplace spirituality menyebabkan meningkatnya kualitas kehidupan kerja di RSUD dr. Chasan Boesoeirie Provinsi Maluku Utara.

\section{Saran}

Berdasarkan pada hasil pembahasan, dan kesimpulan di atas, maka saran-saran dalam penelitian ini adalah RSUD dr. Chasan Boesoerie perlu untuk meningkatkan spiritualitas melalui: 1) menciptakan lingkungan kerja yang memadai, 2) memberikan motivasi kepada perawat melalui pelatihan-pelatihan diantaranya adalah in the job trainning, 3) memberikan kesempatan kepada perawat untuk mengevaluasi kembali hasil penilaian pekerjaannya, dan 4) memberikan pemahaman kepada para perawat tentang visi, miisi, dan tujuan organisasi secara rinci. Hal ini dapat dilakukan melalui workshop, atau pertemuan-pertemuan resmi yang terprogram.

Selain itu, RSUD dr. Chasan Boesoerie Provinsi Maluku Utara juga perlu untuk meningkatkan kualitas kehidupan kerja melalui: 1) merumuskan kembali sistem kompensasi berdasarkan peraturan yang berlaku, dan mengimplementasikannya secara konsisten. Kompensasi yang dimaksud terdiri dari: Kompensasi langsung maupun kompensasi tidak langsung; 2) menciptakan lingkungan kerja yang aman dan bersih; 3) memberikan kesempatan kepada para perawat untuk mengembangkan diri. Hal ini dapat dilakukan dengan menyelenggarakan Diklat Teknis sesuai dengann bidang tugas masing-masing perawat; 4) memberdayakan perawat secara adil dan memberikan umpan balik atau respon atas berbagai keluhan para perawat; 5) merumuskan SOP disetiap unit RSUD dan mensosialisasikannya kepada perawat; dan 6) mengidentifikasi dan menyediakan fasilitas kerja sesuai dengan kebutuhan perawat di seluruh unit RSUD.

Perawat RSUD dr. Chasan Boesoerie Provinsi Maluku Utara perlu untuk: 1) bekerja sesuai dengan tugas dan fungsi pokok; 2) membuat atau bersedia melakukan evaluasi kembali atas hasil kerja secara mandiri, dan selalu berkoordinasi dengan rekan kerja dan atasan langsung; 3 ) bersedia mengemukakan gagasan ketika dibutuhkan oleh atasan langsung, 4) bersedia bertanggungjawab atas konsekuensi apapun yang dihasilkan dalam pekerjaan, 5) mempelajari dan memahami visi, misi, dan tujuan RSUD secara umum dan khususnya unit kerja; dan 4) bersedia menggunakan fasilitas kantor (seperti komputer atau internet) hanya untuk kepentingan pekerjaan. Bagi peneliti lain yang ingin mengembangkan penelitian ini, perlu melakukan penelitian yang menggunakan variabel-variabel yang sama atau berbeda yang memiliki pengaruh terhadap Kinerja. 


\section{DAFTAR PUSTAKA}

Abdurahman., Dudung., dan Prima, M. A. (2011). Hubungan Spiritualitas dan Spiritualitas di Tempat Kerja. Prosiding, Sosial, EKonomi dan Humaniora, Penerbit : Universitas Islam Bandung (UNISBA).

Amalia., Filhaq., dan Yunizar. (2010). Perilaku dan Spiritualitas di Tempat Kerja. Jurnal Bisnis dan Manajemen, Universitas Padjadjaran Bandung.

Anatan., Lina., dan Lena, E. (2007). Manajemen Sumber Daya Manusia dalam Bisnis Modern. Bandung: Alfabeta.

Arifin, N. (2012). Analisis Kualitas Kehidupan Kerja, Kinerja, dan Kepuasan Kerja Pada CV. Duta Senenan Jepara. Jurnal Economia, 8(1): 11-21.

Armstrong, M. (2010). Human Management Practice a Guide to People Management. London: Kogan Page Limited.

Ashmos, D.P., dan Duchon, R. D. (2000). Spirituality at Work: A conceptualization and Measures. Journal of Management Inquiry, 9 (2): 134-145.

Bernardin, H. John, 2010. Human Resource Management, An Experiental Approach, Fift Edition. New York: McGraw-Hill Compenies, Inc.

Campbell, J. P. ,1990. Modeling the performance prediction problem in industrial and organizational psychology. In M. D. Dunnette \& L. M. Hough (Eds.), Handbook of Industrial and Organizational Psychology, Consulting Psychologists Press, Inc., Palo Alto, CA: 687-732.

Carayon, Pascale, et al. 2003. Job Characteristics and Quality of Working Life in the IT Workforce. Proceedings of Research Seminar, Department of Industrial Engineering, University of Wisconsin.

Cascio, Wayne F., 2006.Managing Human Resources: Productivity, Quality of Work Life, Profit. Singapore: McGraw-Hill International Edition.

Daft, L. Richard, 2006. Management. Terjemahan oleh Diana Angelica, Jakarta: Salemba Empat.

Dent, E. B., Higgins, T. M., dan Wharff, D. M., 2005. Spirituality and Leadership: an Empirical Review of Definitions, Distinctions, and Embedded Assumptions. Journal The Leadership Quarterly, 16 (5): 625-653.

Javanmard,Habibollah, 2012. The impact of spirituality on work performance. Indian Journal of Science and Technology, 5 (1): 1961-1965

Dharmawan, I Made Yusa. 2011. Pengaruh Kompensasi dan Lingkungan Kerja Non Fisik Terhadap Disiplin dan Kinerja Karyawan Hotel Nikki Denpasar. Tesis Program Pascasarjana Universitas Udayana. Denpasar: Universitas Udayana.

Flippo, E. B. (2005). Manajemen Personalia Jilid 1 (Edisi keenam).Jakarta: Erlangga.

Garcia-Zamor, J.-C., 2003. Workplace Spirituality and Organizational Performance. Public Administration Review, 63, 355-363.

Gupta Vibha dan Meena Saini, 2014. Impact of Spirituality over Job Satisfaction: A Concept. International Journal of Advance Research in Computer Science and Management Studies, 2 (9): 437-442.

Greenberg, Jerald, and Baron, A. Robert, 2003. Behavior in Organization. Understanding and Managing the Human Side of Work Sixth Edition. PrenticeHall International, Inc. 
Hakim, Abdul., dan Aslimin, 2015. Model Peningkatan Komitmen Sumber Daya Manusia Berbasis Spiritual Leadership Dan Spiritual Survival Serta Workplace Spirituality Dengan Moderating Individual Spirituality. Jurnal Accounting, Business, and Management UNISSULA, 9 (1): 344-356.

Hassan Hojjati dan Naser Hamidi, 2015. An Investigation Into the Relationship Between Workplace Spirituality and the Quality of Working Life Case Study: Razan Department of Education. Kuwait Chapter of Arabian Journal of Business and Management Review, 4 (11): 17-26.

Irawati, S. Anugrahini, 2015. Pengaruh Kualitas Kehidupan Kerja Terhadap Kinerja Pegawai Dinas Perindustrian Dan Perdagangan Kabupaten Sampang. Jurnal NeoBisnis, 9 (2): .41-52.

Islam, Md. Zohurul., dan Sununta Siengthai, 2009. Quality of Work Life and Organizational Performance: Empiricalevidence from Dhaka Export Processing Zone. Proceeding of ILO Conference on Regulating for Decent Work, Geneva: International Labour Office, 1-19

Ivancevich, 2010. Human Resource Management, International Edition. New York: McGraw-Hill Componies Inc.

Ivancevich, John M., Robert Konopaske, dan Michael T. Matteson, 2011. Organizational Behavior and Management, Ninth Edition. New York: McGraw-Hill Componies Inc.

Kusnendi, 2008. Model-Model Persamaan Struktural, Satu dan Multigroup Sampel dengan LISREL, Bandung: Alfabeta.

Litzsey, C., 2003. Spirituality in The Workplace and The Implications It Has on Employees and Organizations. 2016, 29 Agustus. [online].Diunduh dari:http://wed.siu.edu/public/department/Litzsey\%20paper.pdf.

Mangkunegara, A.A. Anwar Prabu., 2009. Manajemen Sumber Daya Manusia. Bandung: Remaja Rosdakarya.

Marques, J., 2008. Spirituality at work:Internal growth with potential External Challenges. The Journalfor Quality and Participation, 63 (3): 24-28.

Milliman, et al, 2003. Workplace Spirituality and Employee Work Attitudes. Journal of Organizational Change Management, 16 (4): 426-447.

Mulyono, Adi Wastu., 2010. Hubungan Spiritulitas di Tempat Kerja (STK) dengan Komitmen Organisasi Perawat di RSI Fatimah Cilacap. Tesis Universitas Indonesia.

Nair, G.S. Sandhya, 2013. A Study on The Effect of Quality of Work Life (QWL) on Organisational Citizenship Behaviour (OCB) - With Special Reference to College Teachers is Thrissur District, Kerala. Integral Review-A Journal of Management, 6 (1): 34-46.

Nanjundeswaraswamy, T. S., dan Swamy, 2013. Review of Literature on Quality of Work Life. International Journal for Quality Research, 7 (2): 201-214

Naude, Rose., 2010. Quality of Work Life of Front Office Employees in Selected Accommodation Establishments. Unpublished Disertation, North West University.

Newstrom, John W., dan Keith Davis, 2002. Organizational Behavior Human Behavior at Work, Eleventh Edition. New York: McGraw-Hill Componies Inc. 
Nurtjahjanti, Harlina., 2009. Spiritualitas Kerja Sebagai Ekspresi Keinginan Diri Karyawan Untuk Mencari Makna Dan Tujuan Hidup Dalam Organisasi. Jurnal Psikologi Undip, 7 (1): 27-30.

Otiende, Ogolla, Gilbert., 2010. Effects of Quality Work Life on The Performance of Public Health Workers In Kenya: A Case Study of Kenyatta National Hospital, Kenya. Thesis, School of Business, Kenyatta University.

Parmin, 2014. Pengaruh Kualitas Kehidupan Kerja, Disiplin Kerja dan Kompetensi terhadap Kinerja Pegawai pada PD. BPR BKK Kebumen. Jurnal Fokus Bisnis, 14 (2): 81-106.

Peraturan Pemerintah Republik Indonesia Nomor 46 Tahun 2011. Tentang Penilaian Prestasi Kerja Pegawai Negeri Sipil Pasal 1, ayat 3.

Petchsawanga, Pawinee., 2012. Workplace Spirituality, Meditation, and Work Performance. Department Faculty Publications. Paper 92.

Pradhan, et al., 2015. Workplace Spirituality and Employee Performance: Mediating Role of Organisation Citizenship Behaviour. Journal of Contemporary Psychological Research, 2 (1): 40-48.

Robbins, Stephen P., dan Timothy A. Judge, 2011. Organizational Behavior and Management, Ninth Edition. New Jersey: Pearson Education, Inc.

Sajjad, Noushin Kamali, dan Badri Abbasi, 2013. Studying the Relationship Between Quality of Work Life and Organizational Commitment. Journal of Recent Sciences, 3 (2). 92-99

Sekaran, Uma. 1992. Research Methods For Business: A Skill Building Approach, Secon Edition, John Willey \& Sons, Inc. New York.

Sheel, Shalini, et al., 2012. Quality of Work Life, Employee Performance and Career Growth Opportunities: A Literature Review. International Journal of Multidisciplinary Research, Vol. 2 (2). 291-200.

Stone, J. Raymond, 2005. Human Resource Management", Fifth Edition. John Wiley \& Sons Australia, Ltd 42 McDougall Street, Milton, Australia.

Strack, Gary et al., 2002. Spirituality and effective Leadership in Healthcare: Is There a Connection?. Frontiers of Health service management, 18 (4): 3-14

Supardi, 2013. Aplikasi Statistika dalam Penelitian Konsep Statistika yang Lebih Komprehensif. Jakarta: Change Publication.

Taghavi, Safura, et al., 2014. A Study of the Relationship Between Quality of Work Life and Performance Effectiveness of High School Teachers' in Shirvan. International Journal of Academic Research in Business and Social Sciences, 4 (1): 295-301.

Undang-Undang Republik Indonesia Nomor 44 Tahun 2009 Tentang Rumah Sakit.

Yogatama, Leo AGung Manggala., dan Widyarini, Nilam., 2015. Kajian Spiritualitas di Tempat Kerja pada Konteks Organisasi Bisnis. Jurnal psikologi, 41 (1): 1-14. 